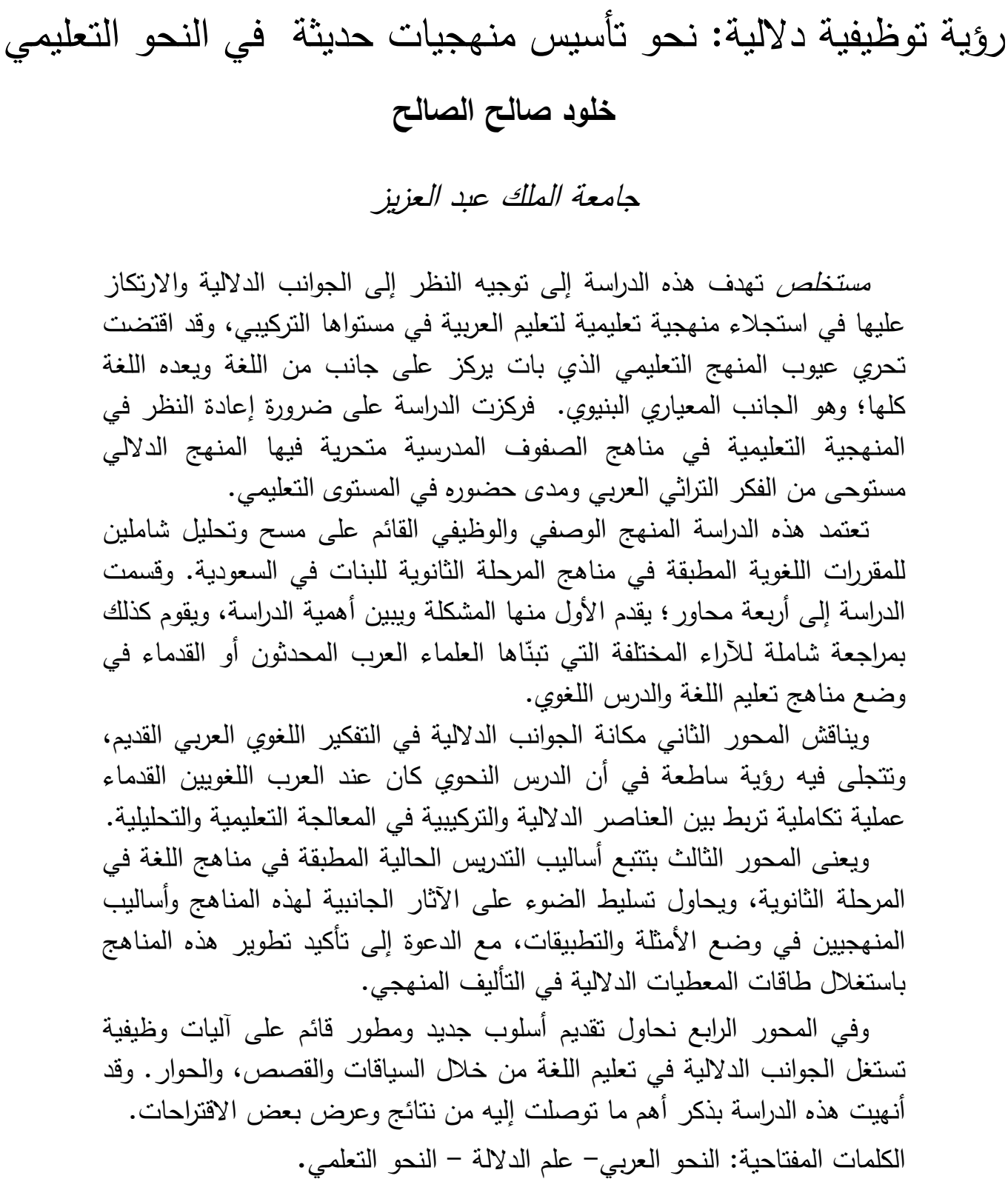

العناية كثيرًا بالجوانب الدلالية التي هي الأصل في

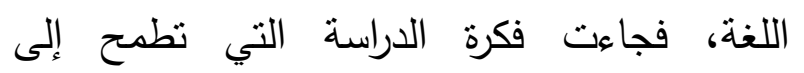

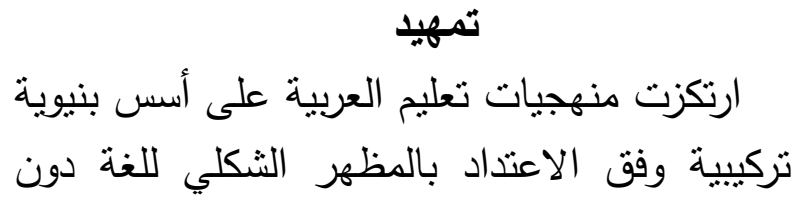


في كتابه؛ إذ إن كتابه بعد من أقدم الدصادر التي

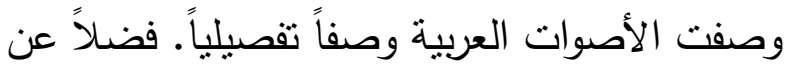

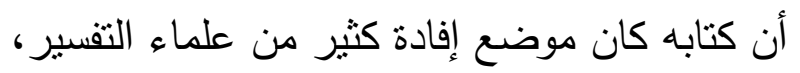
وفي هذا الصدد يقول أبو حيان الأندلسي في مقدمة عان أنياء

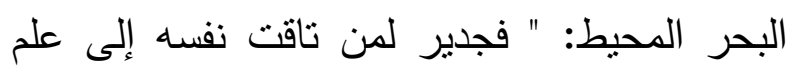

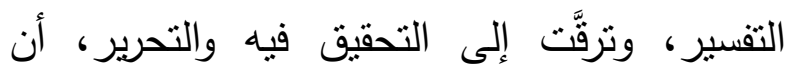
يعتكف على كتاب سيبويه فهو من الفن الفئ المعوَّل عليه، والمستتد في حل المشكلات إليه". كما أفاد

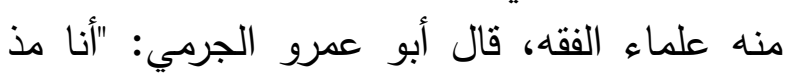

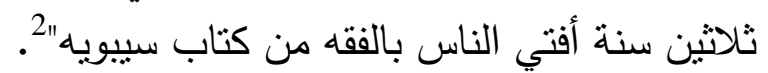

كما أفاد علماء الأصول من النحو إفادة بالغة

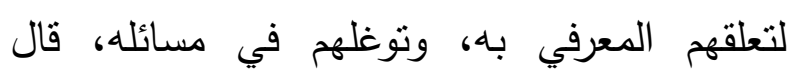

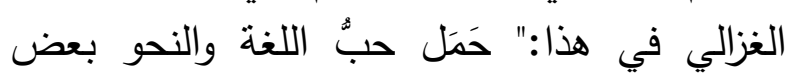
الأصوليين على مزج جملة من النحو بالأصول فذكروافيه معاني الحروف ومعاني الإعراب جملاً

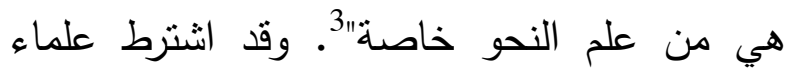

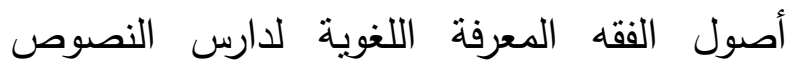

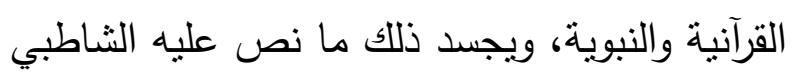
من أن شرط المجتهد في الأصول الفقهية أن يتقن

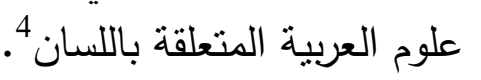

1 أبو حيان الأندلسي، البحر المحيط، تحقيق: عادل عبد الموجود،

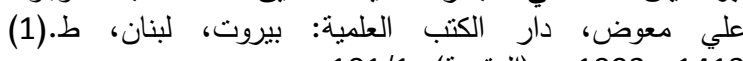

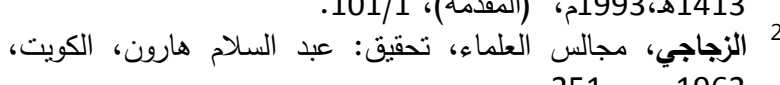

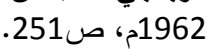

أبو حامد الثزالي، المستصفي في علد الأصول، تصحيح: محمد

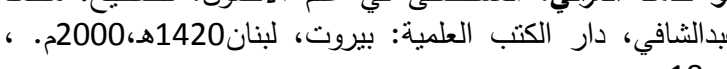
4

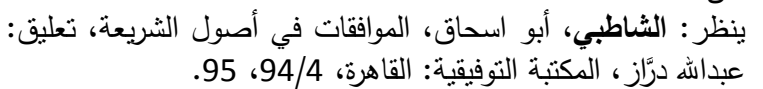

المشاركة في تأسيس منهجيات تعليمية للمستوى

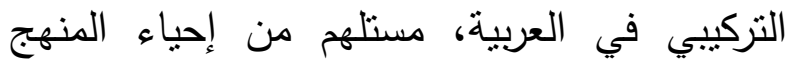

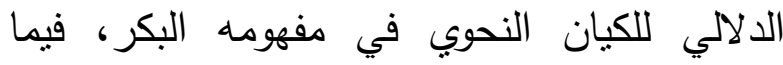
يستلزم استجلاء ملامح النحو العربي في مادته

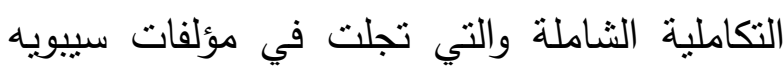

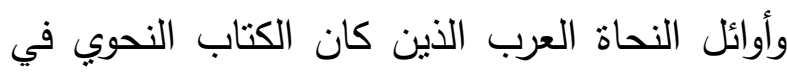
منظورهم هو مألت مادة اللغة بأصواتها، و ومبانيها، وتراكيبها، ودلائلها، فيما تشكل معًا وسيلة التعبير

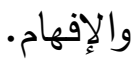

لقد كان لسلف الأمة العربية تصور كلي للحياة الفكرية والعلمية، وكانت تتتهج أسلوب الامنتاج

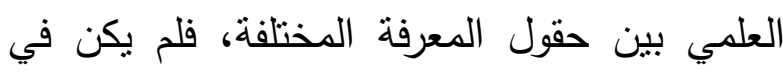

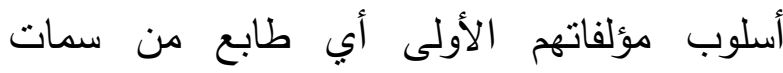

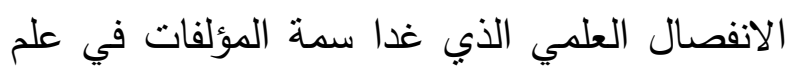

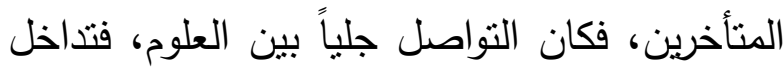

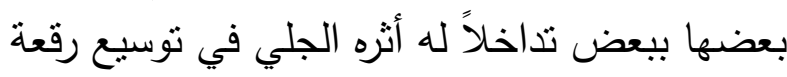

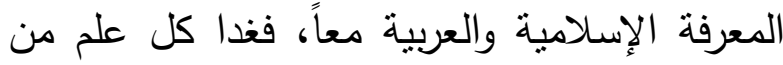

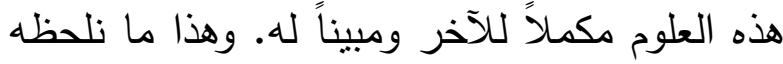

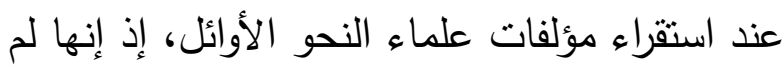
تكن قاصرة على قضايا النحو وأصوله، إنما كانت التهاء

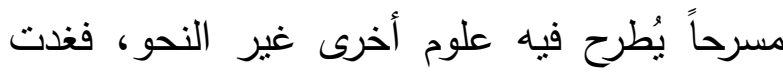
أطروحات الرعيل الأول من علماء الخري النحو واللغة نبعاً بستقي من جداوله عدد كبير من العلوم، فأفاد منه الرهاء

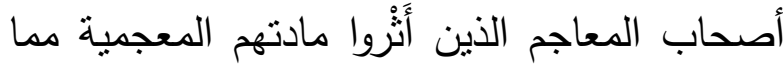

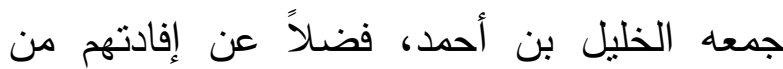

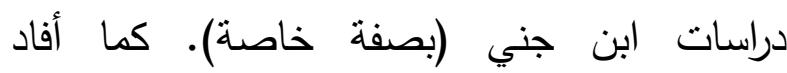
أصحاب علم التجويد من دراسات الخليل وتلاميذه

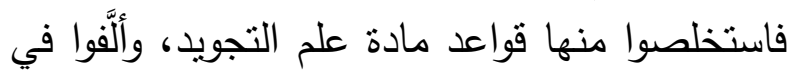

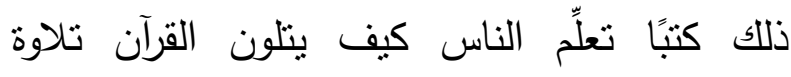
صحيحة، كما أفادوا من المادة التي قدمها سيبويه 
المسائل، وتداعت الخلافات العلمية بين العلماء، وبدلاً من أن يكون هذا التقسيم مدعاة لتطوير المنهجية الفكرية في كل حقل خاص منها، أدى إلى هلى

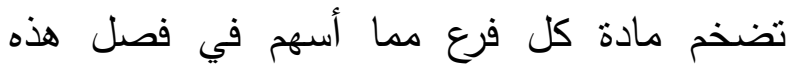

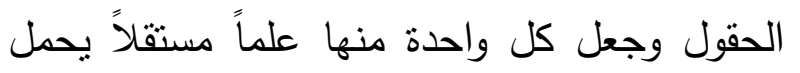
مسمى طابع المعرفة التي يحملها بين دفتيه،

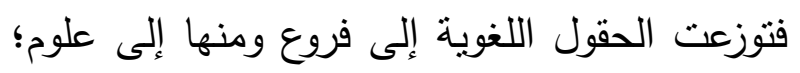
فجاء علم النحو والصرف، واللغة، والبلاغة، بل فيل وتفرع كل علم من هذه إلى فروع أخرى؛ فانفلق

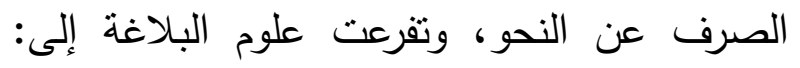
المعاني، والبيان، والبديع. لقد أعقب هذا العزل والانفصال العلمي اللغوي

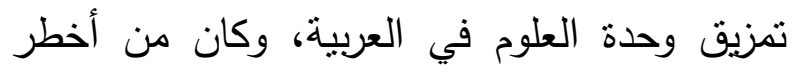
تداعياتها فصل الحقل الدلالي عن الحقل التركيبي

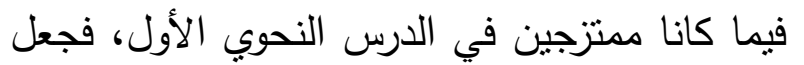

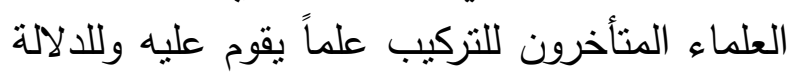

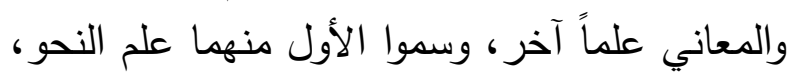

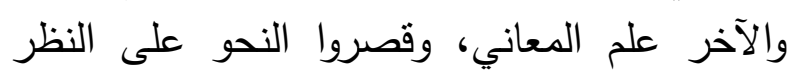
فيما بطرأ على التركيب من تغيير في الثكل، (سواء واء

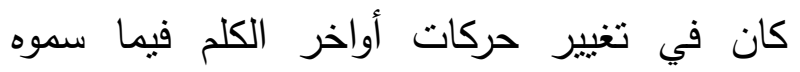
الإعراب، أو في النظر في أجزاء الجملة بتغيير

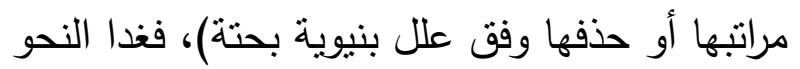

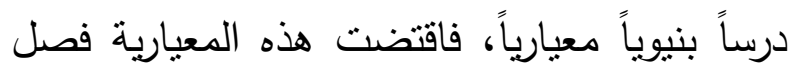

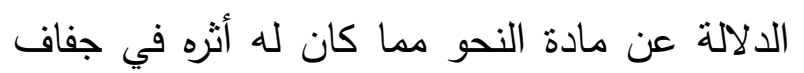
المادة وغياب المضمون، فحرض ذللك على انفصال

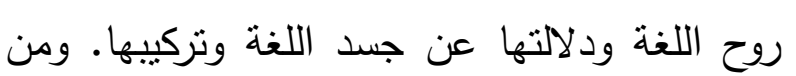
آثار ذلك ما لاحظه ابن الأثير في استقلال النحو

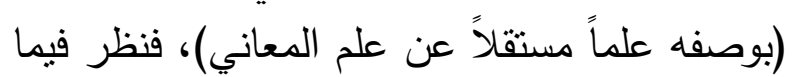
ساد في الدرس النحوي بعد الخليل، وسيبويه، والفراء
أما علماء البلاغة فقد أفادوا من الدراسات

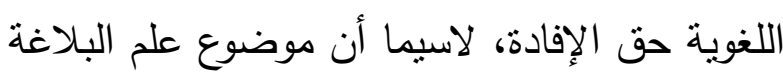

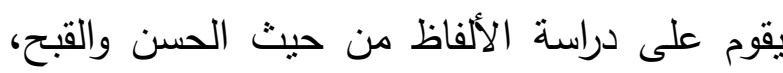

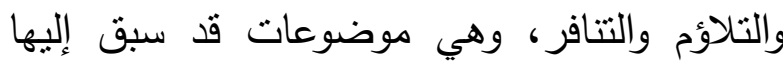
علماء النحو واللغة، ومن بطلع على أوائل أبواب

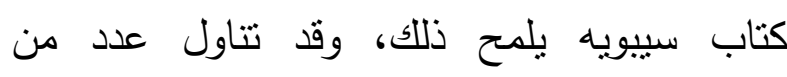

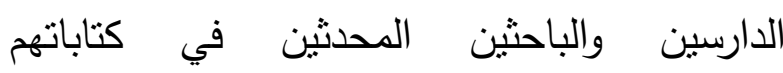
موضوعات تبحث في المواد التي أفاد علماء البلاغة فيها من النحويين واللغويين فيما ارتكزوا إليها في نأليف علم البلاغة بفروعها الثناثة 1.

فغدا الامتزاج العلمي والتداخل المعرفي هو سمة الأدي،

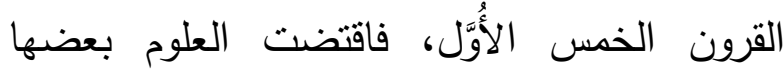

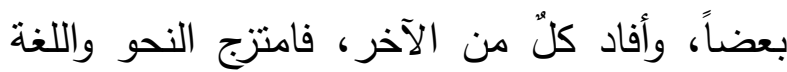

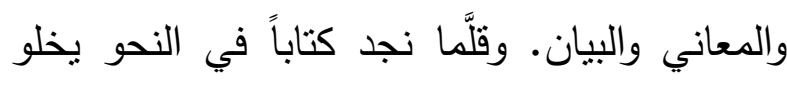
من طائفة قليلة أو كثيرة من الملاحظات التي تتنمي ولي

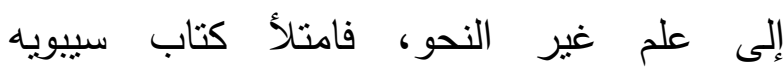
بالملاحظات الدلالية والبيانية والصوتية، ومنل ذلك فئل

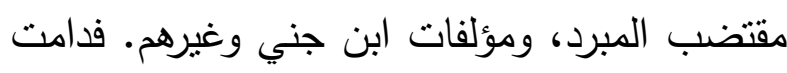
مؤلفات القدامى تحمل شعار الاتصال بين العلوم

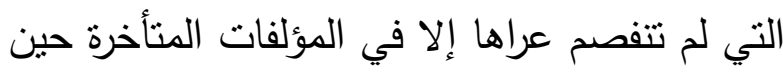
وُضِع لكل علٍٍ منها حدوده، وامتاز بمنهجه، واستقل بأبوابه وفصوله.

وجاء العلماء المتأخرون وفي مناهجهم الفكرية

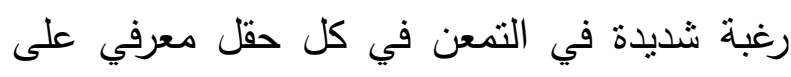

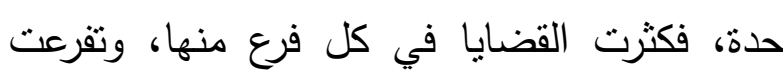
غريب: القاهرة. 
بصورة جلية في كتابه (الإغراب في جدل الإعراب)، فيما جهد ابن مضاء بإسقاطها من هن

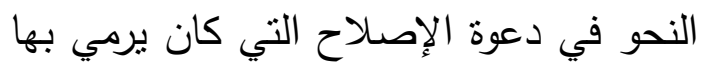
إلى تخليص النحو من شوائب التعقيد الفلسفي الذي جاء به المتأخرون.

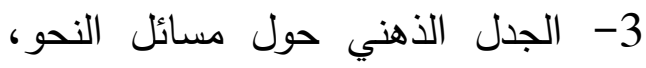

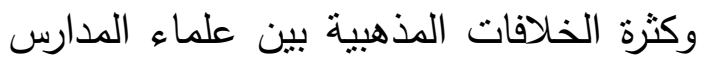

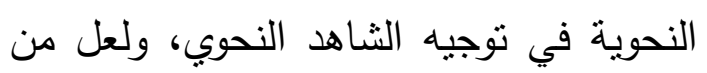
بنظر في إنصاف الأنباري يجد صوراً شنَّى تُونى

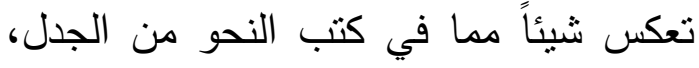

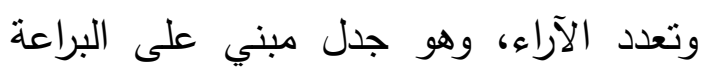
الذهنية دون أن تقدم نفعاً في ضبط الاردي اللغة ونطقها.

4- اللجوء إلى الأقيسة والأمثلة المصنوعة التي لا تتسجم مع الواقع اللغوي، الته

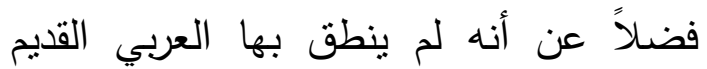

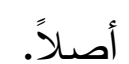

5- وضع أبواب في النحو العربي لا تقف على عتبة فكر تعليمي يمكن تسويغه؛ مثل أبواب الاثتغال والتتازع، فقد تكلف النحاة

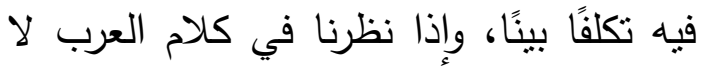

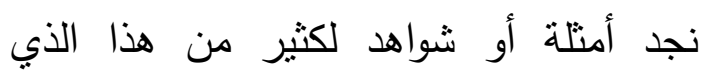
طرحوه، بل إننا نلمس تمجيدهم القواعد التي هنواني وضعوها وإن خالفت المأثقر من الثواهد.

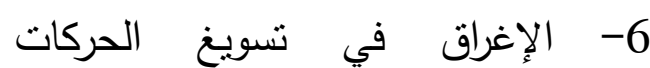
الإعرابية الظاهرة والمقدرة في إطار نظرية

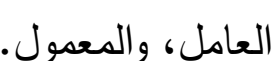

حتى عصره، من اقتصار النحو على معرفة

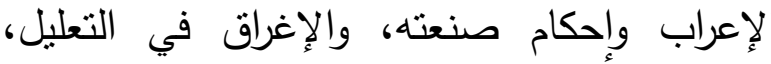
والإيغال في التأويل والتقدير، وكثرة الآراء في

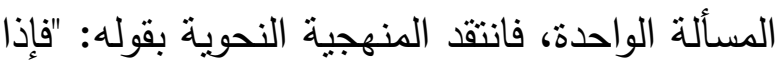
نظرنا إلى ضرورته وأقسامه المدونة وجدنا أكثرها

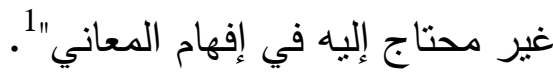

لق تمخض عن مسرب منهج الفصل منطقة

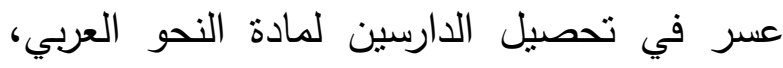
فخلق في نفوسه مشاعر التوجس، وانبرى عن تشقيق المسائل فيها إحساس بالعزوف. واذا نأملنا في جملة أسباب هذا العزوف عن النحو، وعوامل تعقيده وجفافه، نلحظ أنها تقف تحت قائمة بمكن إيجاز أهمها في النقاط الآتية:

1- إفراط النحاة في القول بالحذف، النهاط:

والإضمار، والتأويل، والتقدير؛ تللك الأصول التي استتها النحاة وجعلوها قنوات باطنية تساعدهم في تمرير الثواهد الفصيحة دون الاصطدام بالقواعد المعيارية التي وضعوها،

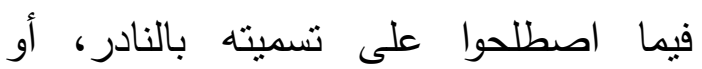
القليل، أو الثناذ الذي يحفظ ولا يقاس عليه، فكانت هذه الأصول هي باعث النحاة في تخطئة بعض ما روي عن العرب، ونتذيذ هاعي الاهن قسم من القراءات القرآنية، وتعدد الأوجه في العبارة الواحدة.

2- الإغراق في التعليل والقول بالعلل

الثواني والثوالث التي تعرَّض لها الأنباري

1 $1{ }^{1}$

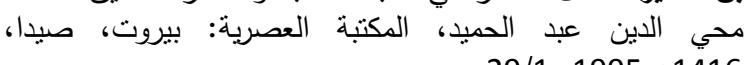


أولى في محاولات إصلاح النحو وإسقاط مالا يفيد نطقًا، وهو موضوع طويل ليس ميدانه هنا. وهكنا تتكل من معيارية الرؤية التقعيدية ومنهجيتها البنيوية منهج نحوي يصطبغ بتعقيدات الفلسفة ومنطقية التعليلات التي أثرت على آليات

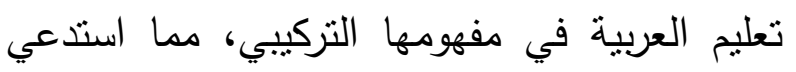
تكثيف الطرح في الروئة التراثية المرنة وتطويرها وفق المعطيات الحديثة ومحاولة تقليل هيمنة المنهج النحوي البنيوي في كونه علمًا جدلياً بحتًا، يغرق في

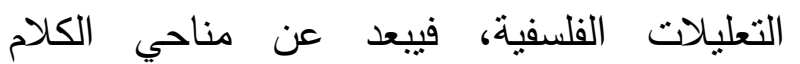
وغاياته، ويبدل وظيفة النحو الأم التي تقتضي درسيًا يجمع بين التزكيب والدالة باحثًا في أبنية التراكيب

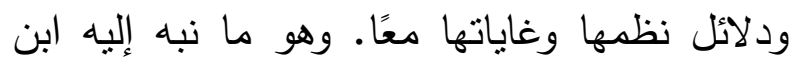
خلدون، حيث أنكر على القدماء تضييقهم النحو نائه وتوظيفهم الجدل المنطقي في المنهج التعليمي، وقصنر غاية النحو عليه، وقد أحسن التعليق على التى التطائ هذا المسرب إذ قال:"فأصبحت صناعه وضاعة العربية كأنها من جملة قوانين المنطق العقلية أو الجدل، وبعدات العادئ

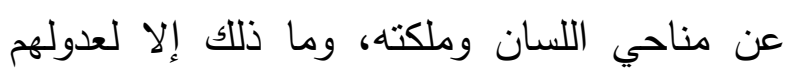
عن البحث في شواهد اللسان وتراكييه وتمييز أساليبه، وتلكا القوانين إنما هي وسائل للتعليم، لكنهم

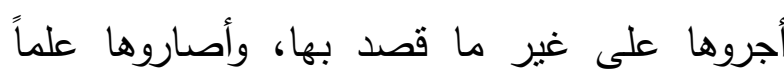

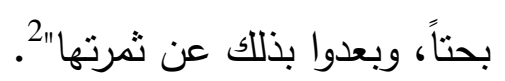
فكان هذا الدنهج النحوي هو الدنهي النهج الددرسي الذي سارت عليه مؤلفات جمهرة النحاة المنأخرين، $2{ }^{2}$

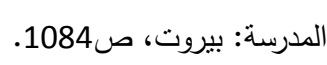

ومن هنا جاء النحو جافًا من جفاف المنطق

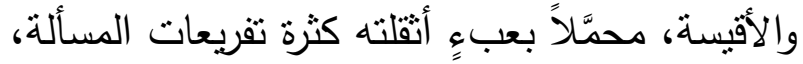
علاوة على المجادلات التي هي من آثار إعمال

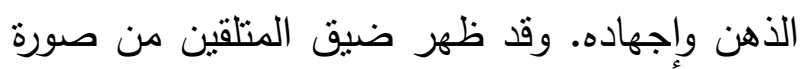
النحو هذه حتى من طلاب النحو المتفرغين، وقد

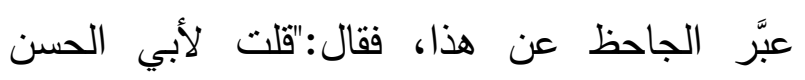

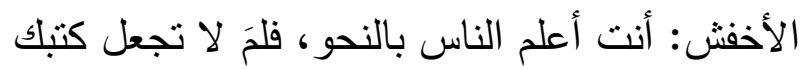

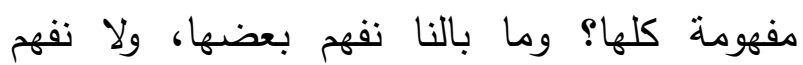

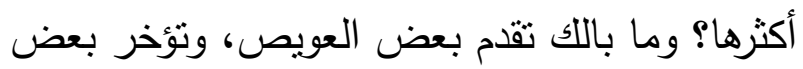

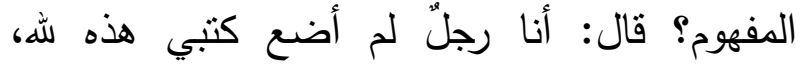

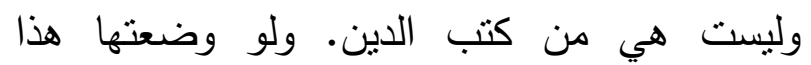
الوضع الذي تدعو إليه قلَّت حاجاتهم إليَّ فيه. وإنما قد كسبت في هذا التدبير، إذ كنت إلى التكسب التهب ذهبت". فكان لهذا أثنره على المتعلمين والناطقين على حدٍ سواء، فاشتت عود الخصومات والمشاحنات التئي كانت تقوم كثيرًا بين الناطقين الفصحاء وعلماء

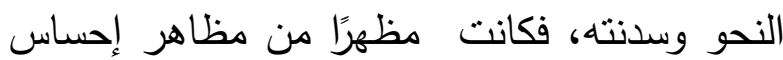

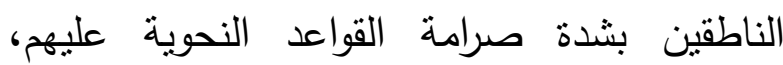
وضيقهم بما يشهره النحاة في وجوههم من أقبيسة جدلية. وقد روت كتب اللغة والأدب مواقف لا تكاد تحصى عن ذلك النزاع والصراع. هذا من جانب، ومن جانب آخر فقد أحس طائفة من النحاة قديمًا بنقل النحو وعبئه على التتعلمين، فنتبهوا إلى الى الى ضرورة التيسير على المتعلمين، فكان نتيجة ذلك أن أن الثين

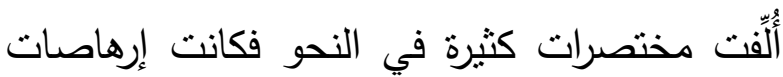
1 الجاحظ، الحيوان، تحقيق: عبدالسلام هارون، القاهرة 1356هـ، $.92 ، 91 / 1$ 
إطار الدرس البراجماتي · . وقد اختقى أثز هذه الروية الثمولية المنهجية في الدرس القديم عند الثراني علماء النحو المتأخرين بسبب دعوتهم لضرورة فصل العلوم، فغدا النحو مصبوغًا بالفلسفة مقصورًا على الإعراب وتتبع أثز العامل، وكأن مفهومه لا لخاعل

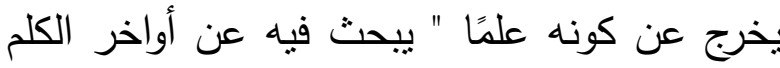

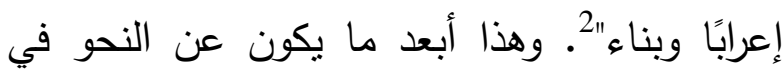
مفهومه الدلالي عند أوائل النحاة، فقد كان فأن فائيًا على تتبع التراكيب بناءً ودلالة، وهو عندهم :"انتحاء سمت كلام العرب في تصريفه من إعراب وغيره

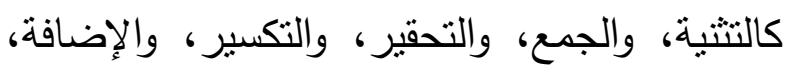

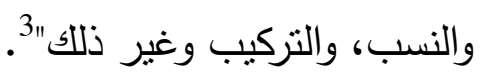
ويبدو أن هنالك فرثًا بين التعريفين؛ إذ إن النحو في التعريف الأخير يرادف مصطلح النظم التركيبي

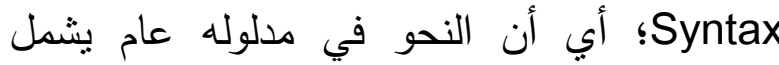

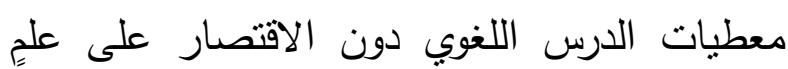
واحد منها، وهذا هو لب ما توصلت إليه الدراسات

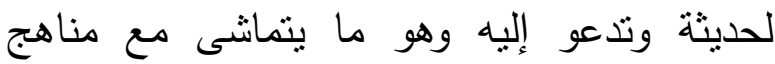
العرب القدماء في إدراك قيمة تلازم العلوم بمنهجية علمية تكاملية.

See: Benz, Anton, Jäger Gerhard, Rooij, Van, Robert (edited), Game theory and pragmatics, Palgrave Macmillan, 2006.Blutner, Rienard, Berlin, Lexical Semantics and Pragmatics, Intercultural Pragmatics, Linguistics-communication Journal, volume 3-nomber1,

2 الصبان، حانثية الصبان، دار إحياء الكتب العربية: القاهرة، فيصل

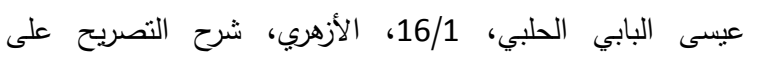
التوضيح، دار إحياء الكتب العربية: القاهرة، 14/1.

$33^{3}{ }^{3}$

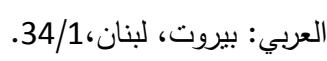

فغدا مسربًا أطرّ النحو بالمعيارية التي تحكم الكلام

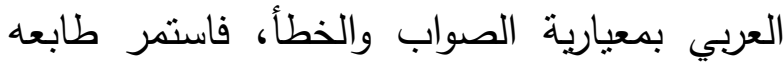
هذا إلى أن تأصل في مناهج الدراسة لتعليم الناشئة قواعد النحو إلى يومنا هذا. ومن هنا تبلورت مشكلة

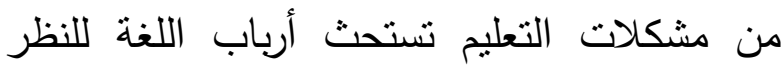
فيها، فقامت عدة محاولات هدفها التيسير ، فتجاذبت لهن

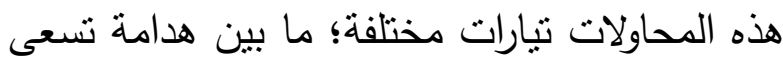
إلى هدم النحو أو لغته واستبدال أبجديته بأحرف غير عربية، أو تيارات متوسطة تبحث في مناطق

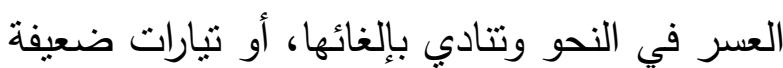
نادت بالتيسير دون أن تقدم فيه شيئًا. وقد قُدمت فيارت أطروحات كثيرة في محاولات التيسير النحوي، دانيا. تنتابه في جوانب وتختلف في أخرى، إلا أنها لم

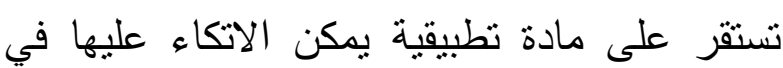

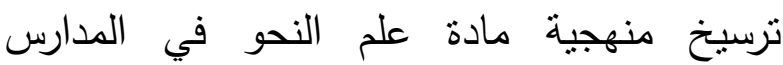

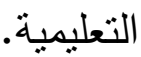

\section{المفهوم الدلالي في منهجية النحاة واللغويين}

الأوائل

لقد كان منهج جل نحاة العربية الأوائل منهجًا دلالياً في الفكر النحوي، فغدوا يدرسون التراكيب وفق وظيفة الإبلاغ وإيصال المعنى، كما كانوا لئل يحتكمون إلى المعنى في تعليل الظواهر اللغوية.

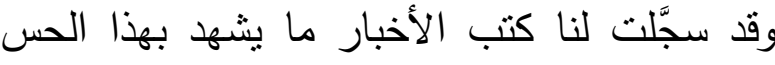

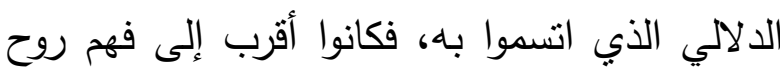

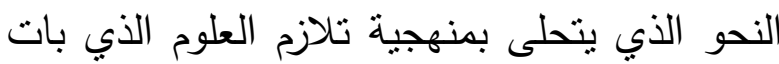

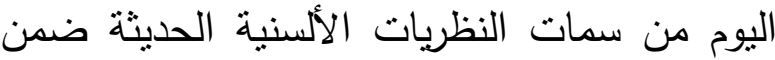


"الحركات"وضـت في الأصل لفهم هذه المعاني"، وقد قال أبو حيان:"والكلام يتغير المراد فيه باختلاف

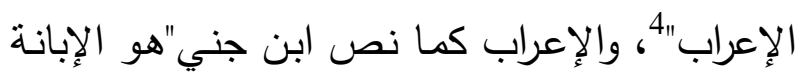

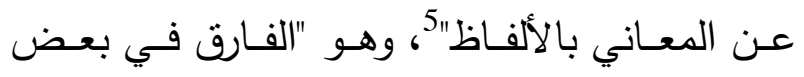

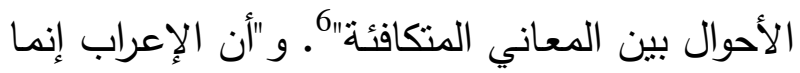

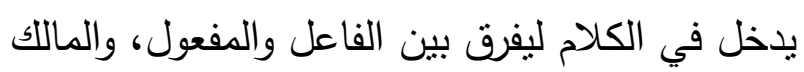

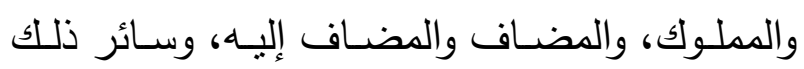

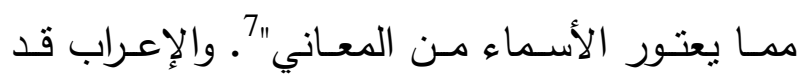

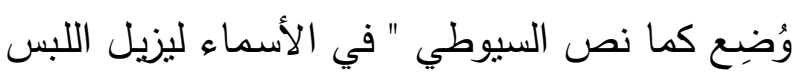

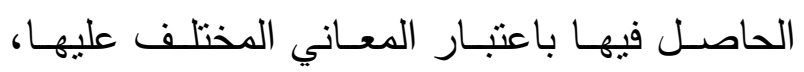

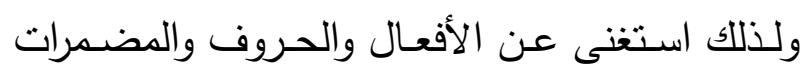

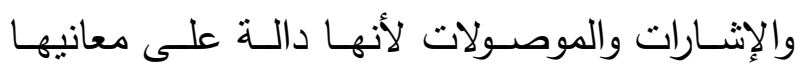
بصيغها فلم تحتج إليه"8، بل إن الإعراب "من أحسن

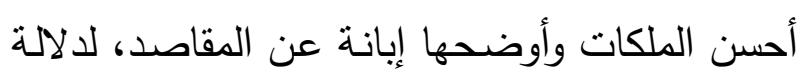
غير الكلمات على كثثر من المعاني، مثل الحركات

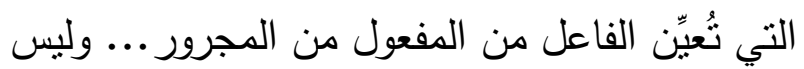

33 البسيط في شرح جمل الزجاجي، 172/1.

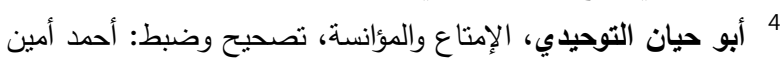

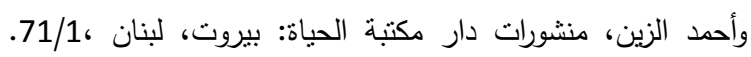

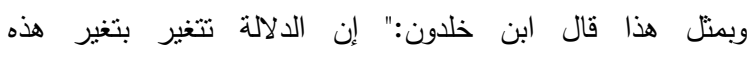

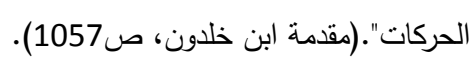
5 الخصائص، 35/1. 6 ابن قتيبة، تأويل مشكل القرآن، تحقيق: السيد أحمد صقر ، مكتبة دار

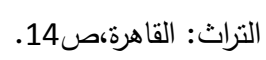
7 أبو القاسم الزجاجي، الجمل في النحو، ، تحقيق: علي الحمد، مؤسسة

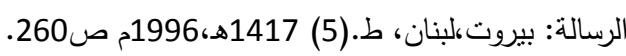

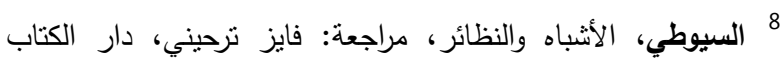
العربي: بيروت-ط.(3)-1417هـ، 1996م، 335/1.
أما النحو في التعريف الأول فيعنون به النحو

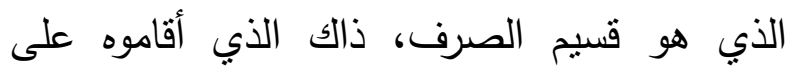
النظر في الحركات الإعرابية وتبريرها بمعزلٍ عن الفري علوم العربية الأخرى، أو بعبارة أخرى بمعزلٍ عن الإبلِ

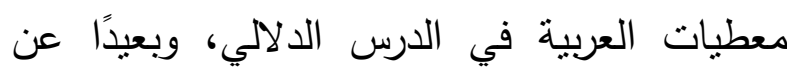
إدراك وظيفة النحو أصلاً، تلك التي تمثل فحوى ما لـاء جاء في نص الزجاجي حين سأل عن الفائدة من تعلُّم النحو وأكثر الناس يتكلمون بغير إعراب ولا لان معرفة به، فأجاب: "الفائدة فيه الوصول إلى التكلّ بكلي

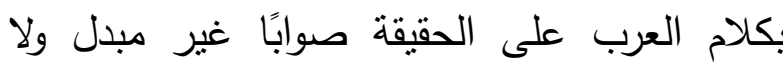
مغيَّر، وتقويم كتاب الله عز وجل، الذي هو أصل

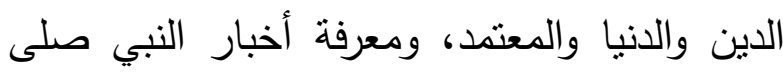

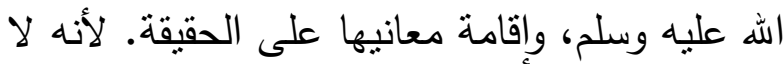

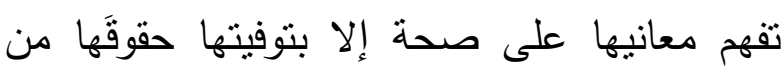

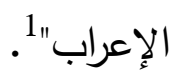

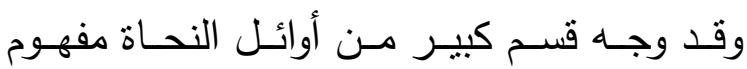

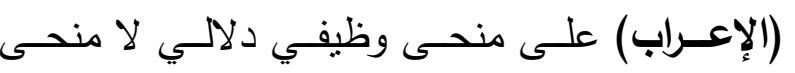

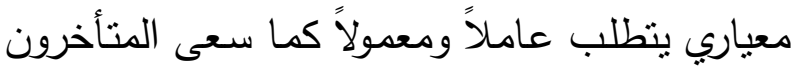

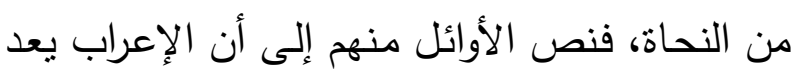

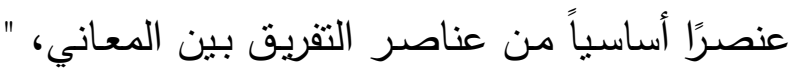

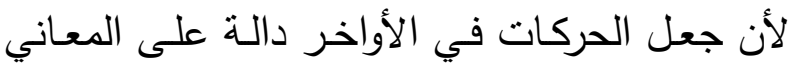

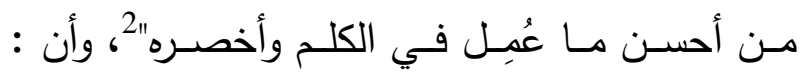
$1{ }^{1}$ النفأس:بيروت، ط.(1) 1394ه، 1974م ، ص95. 2 ينظر : ابن أبي الربيع، البسيط في شرح جمل الزجاجي، تحقيق:

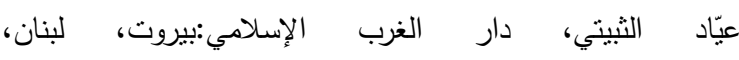

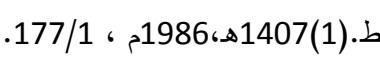


الاستدلال على وجوه الإعراب، وعلى رأس هؤلاء

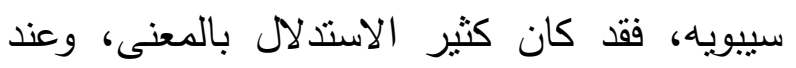
النظر في كتابه نجد وجه المعنى مقدمًا في كلامه. ونضرب لذلك مثالاً من كتابه من نحو استخلاله

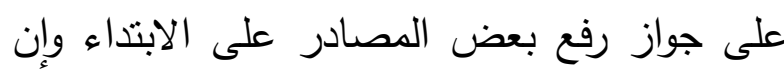

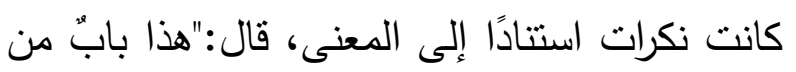

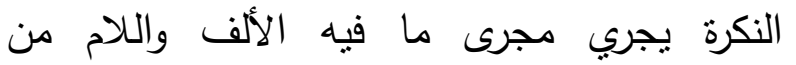

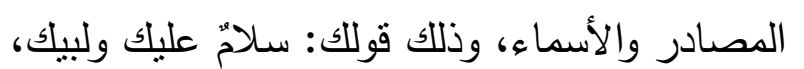

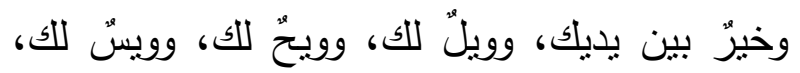

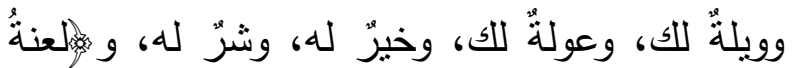

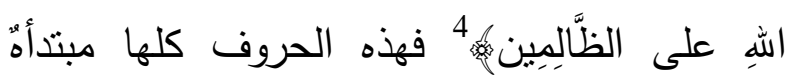
مبنيّ عليها ما بعدها، والمعنى فيهنّ أنك ابتدأت

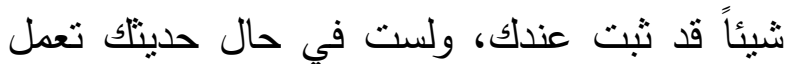

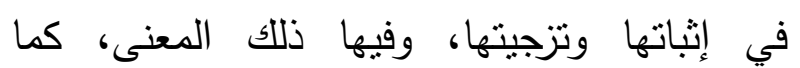
أن(حسبك) فيها معنى النهي، وكما أن(رحمةُ الله

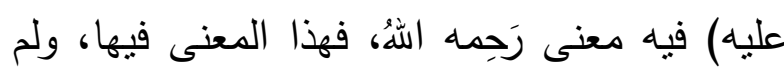

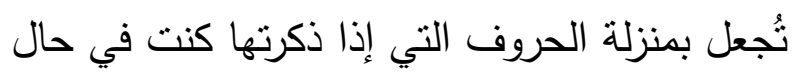
ذكرك إياها تعمل في إثباتها وتزجيتها" وقد أكد مراعاة المعنى عند الإعراب غير فئ واحد من النحاة، فصرح بذلك ابن جني، فقال:"وذلك أنك تجد في كثنرٍ من المنتور والمنظوم الإعراب والمعنى متجاذبين: هذا يدعوك إلى أمر وهذا يمنعك الجكئ

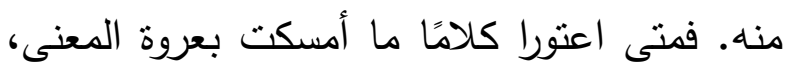

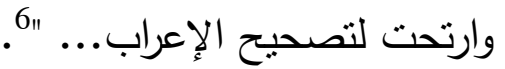
4 هود : 18 5 سبيويه، الكتاب، تحقيق:عبد السلام هارون، مكتبة الخانجي:القاهرة،

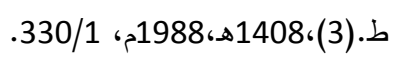

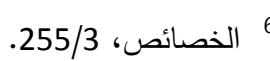

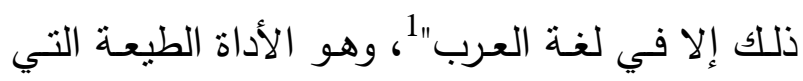

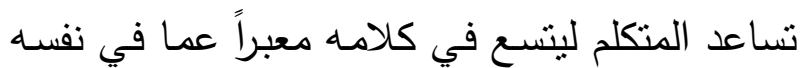
من معانٍ فالإعراب الذي فهمه اللغويون والنحاة الأوائل،

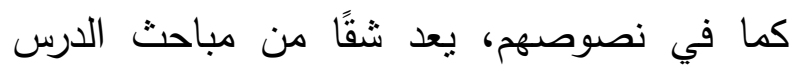

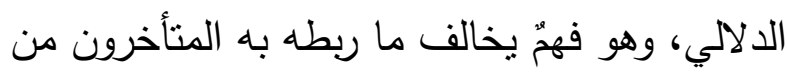

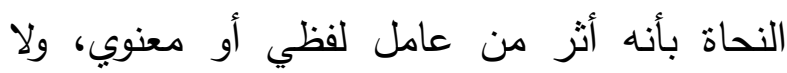

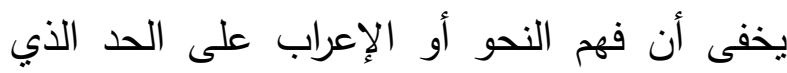

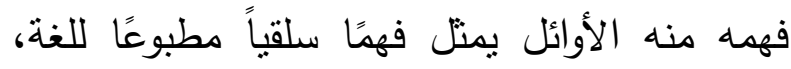

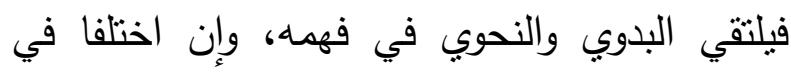

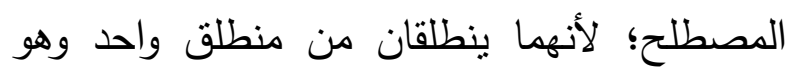

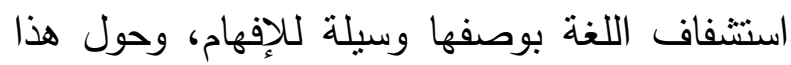
قال عبدالقاهر الجرجاني:"إن الاعتبار بمعرفة مدلول ولئه

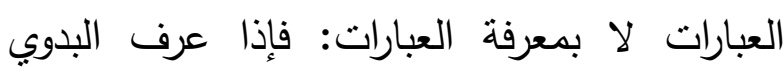
الفرق بين أن يقول: جاعني زيدٌ راكبًا، وبين قوله:

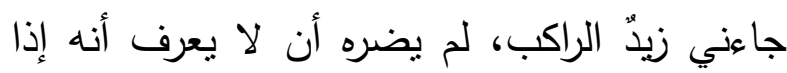

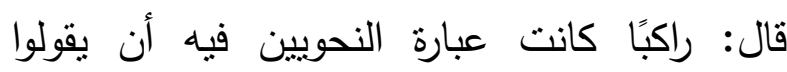
في(راكب) أنه حال، وإذا قال(الراكب) أنه صفة أنة جارية على زبد...." في انه

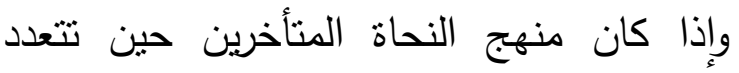
الإعرابات في كلمة واحدة أنهم يتكئون على معيار

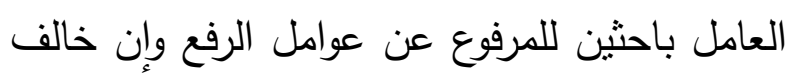
التخريج ما تقتضيه الدلالة في الجملة، فإن الأوائل

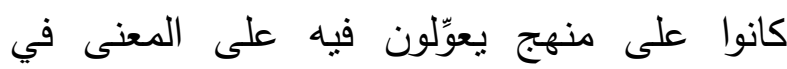
13 مقدمة ابن خلدون، ص1056 وينظر : ص1057. 2 ينظر : الإيضاح في علل النحو، ص69، صنان، 70. $3{ }^{3}$ عبدالقاهر الجرجاني، دلائل الإعجاز ، دار المعرفة: بيروت، لبنان ، ص321. 
(ضربثُ زيدًا) و (زيدّ ضربته) أنكا إذا قلت: ضربثُ

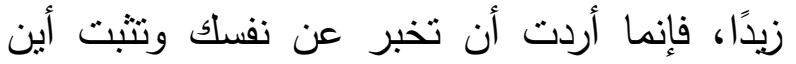

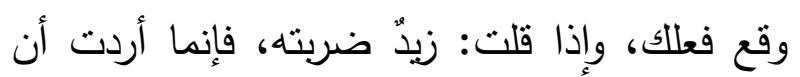
تخبر عن زيد"2. وإذا تأملنا جلياً في قسمٍ من من مؤلفات النحاة الأوائل نجد فيها مظهرًا آخر من مظاهر الدالالة، فئا فئات وييرز ذلك بوضوح في احتكامهم إلى المعنى في تعليل كثيرٍ من الأحكام النحوية. ومن ذلك ما رواه ابن جني من تعليل النيل نأنيث الفعل مع الفاعل المذكر، فقال: "دكى الأصمعي

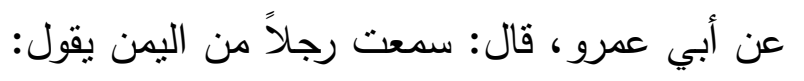

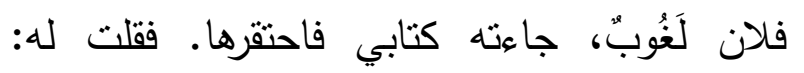

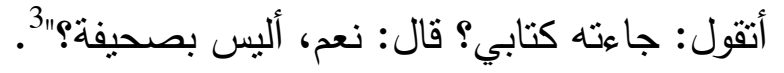

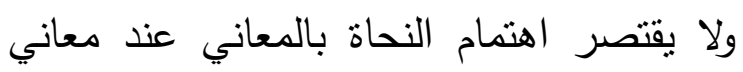

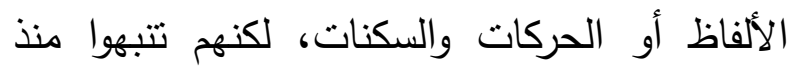

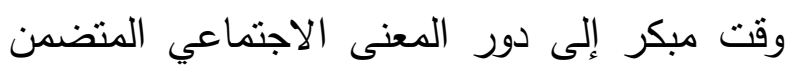

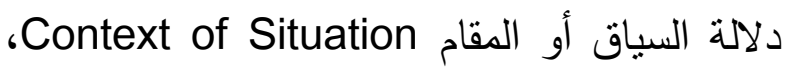
وأثثره في إيضاح دلالة النراكيب والنصوص. فأقاموا

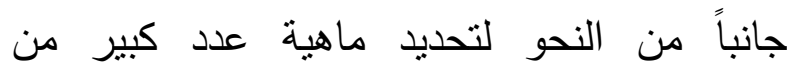
المفردات وتحديد مقاصد الجمل بناء على ما يحدده السياق أو الكقام من وجهة دلالية، فكانت هذه اللفتة

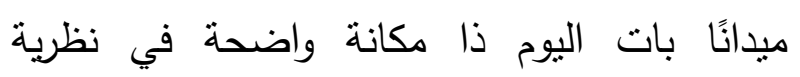
المعنى، بل يلتقي مع ما تنادي به اليوم الدراسات Functional اللغوية الحديثة وفق المنهج الوظيفي (Method

الإيضاح في علل النحو ، ص136، 137.

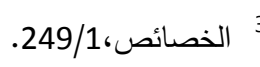

كما اعتتى الأوائل من النحاة واللغويين العرب

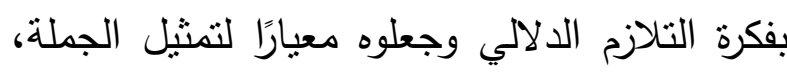

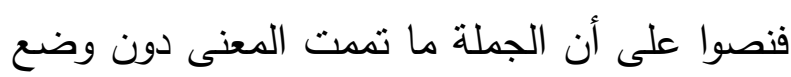

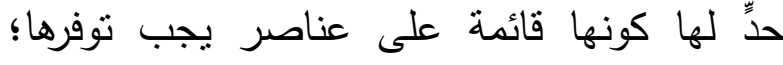
وهي ما اصطلح عليه المتأخرون بالإسناد وركنيه: المسند والمسند إليه، فيما أحالوها من مفهوم دلالي الحي

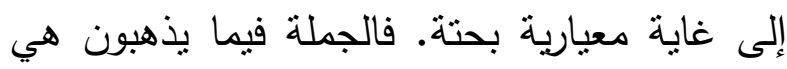

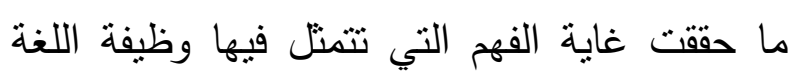
بين المرسل والمستقبل، يقول ابن جني:"ما جنيت منه ثمرة معناه...". وفي هذا النص يتجلى فهم

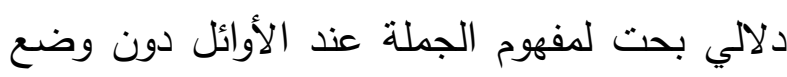
ضوابط معيارية تقنن كون التركيب جملة عربية

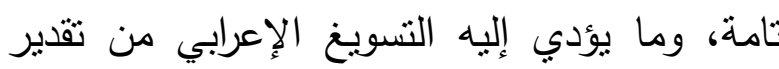
للمحذوف في حال سقط عنصر من العناصر التي أسسوا عليها البناء الجملي.

ومن المظاهر الأخرى للوعي الدلالي عند أوائل

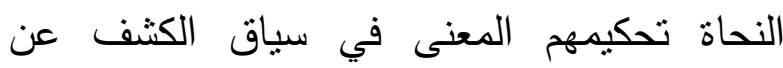
دلالات الأوضاع النحوية، وعلى رأس هؤلاء سيبويه حين أنثار إلى ارتباط بعض الأوضاع النحاع النحوية بدلالات خاصة، وعبارته في بيان أهية التقديم والتأخير خير ما يمثل ذلك، حين قال: "كأنهم

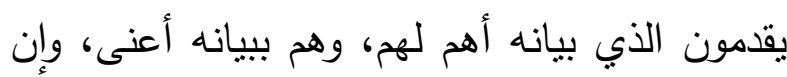

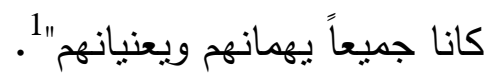
وقد عنى قسمُ من النحاة بعد سيبويه بالكثنف عن الفروق الدلالية للأوضاع النحوية للتركيب، فقد روى الزجاجي أن أبا العباس المبرد قال:"الفرق بين 


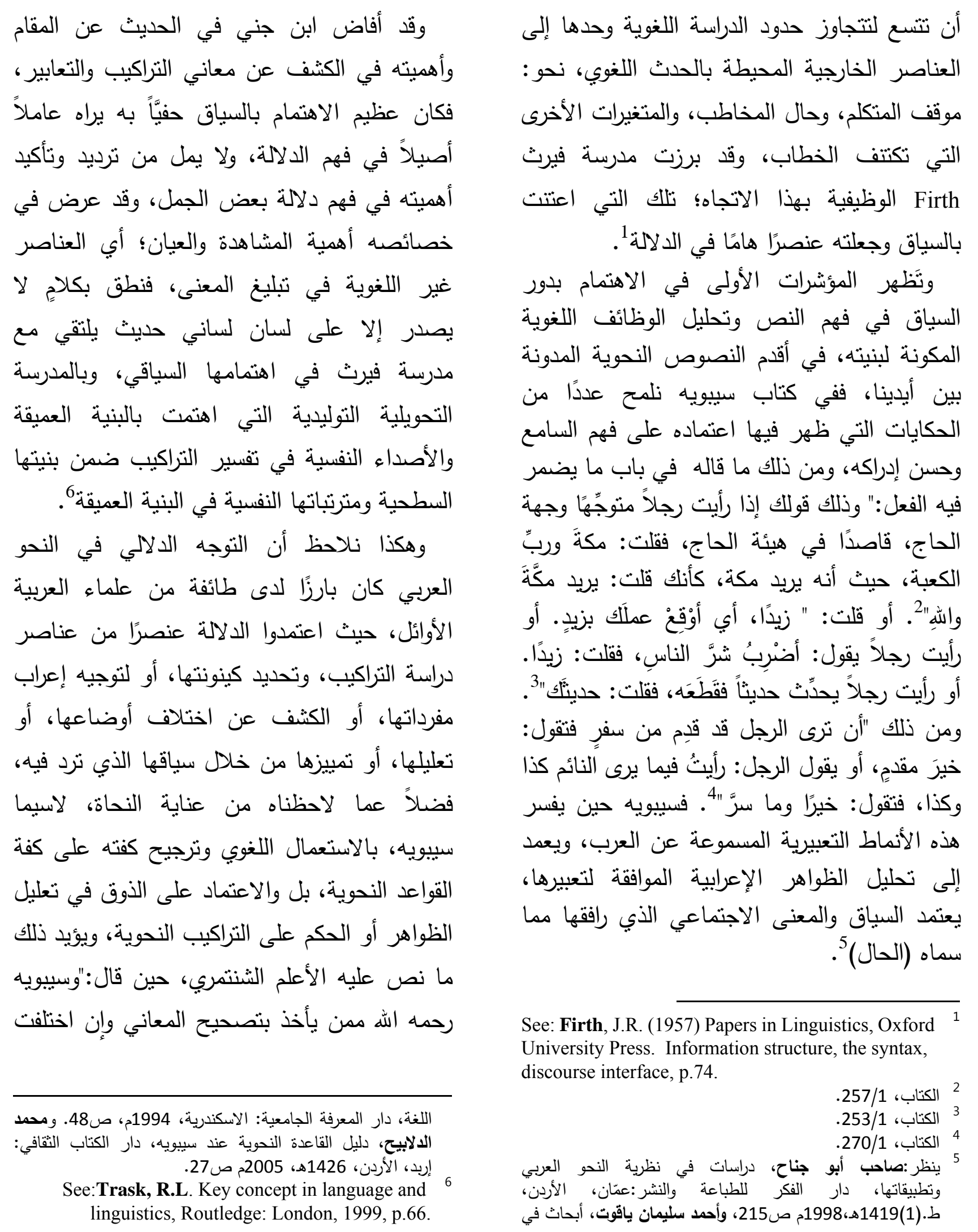


أخرى بأصول فلسفتهم هذه. فضلاً عن جرأتهم في رفض بعض الأساليب العربية المنقولة.

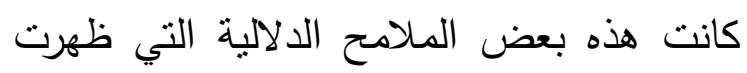
في منهجية النحاة واللغويين الأوائل مما نركن إليها في تأسيس الرؤى المنهجية التعليمية الحديثة لمادة النحو في الصفوف المدرسية.

\section{روية توظيفية دلالية للمنهج التعليمي}

تتأسس الرؤى الوظيفية في إطار الدعوة إلى نى

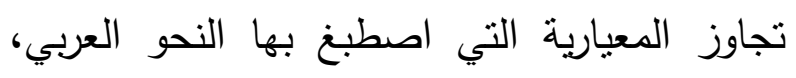

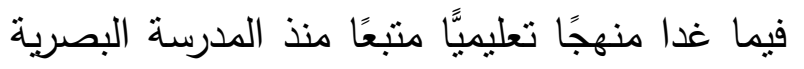
إلى مقررات النحو في المدارس التعليمية التربوية الحديثة، فاحتكم الكتاب المدرسي في نوزيع أبوابه

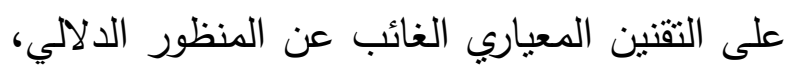

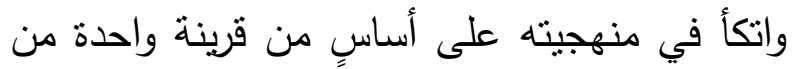
القرائن التي تقنن بها الجمل؛ وهي قرينة الحركة الإعرابية على ضوء نظرية العامل، دون النظر في لفي

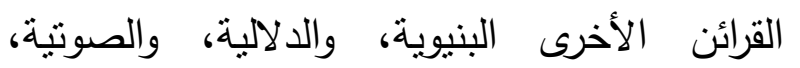

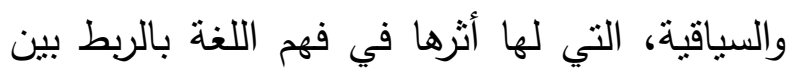
المعنى والمبنى، وينهض على أساسها تحليل تركيبي سليم للجملة العربية.

وسنطبق هذه الرؤية على المنهج المدربة المبية المتبع تعليمياً في المستوى الثانوي للطالبات في لردية مقررات النحو العربي في المملكة العربية السعودية،

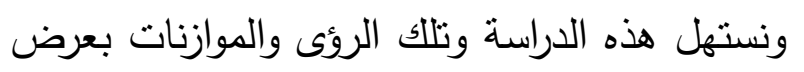

الألفاظ". . ويؤيد ذلك أيضًا ما رد به السيرافي على دلى دن متّى بن يونس في المناظرة التي كانت بين النحو

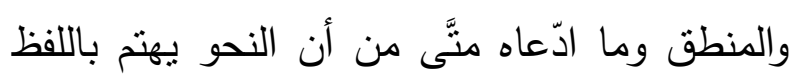

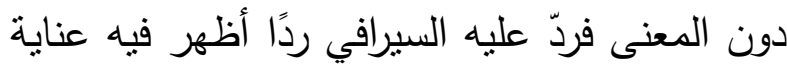

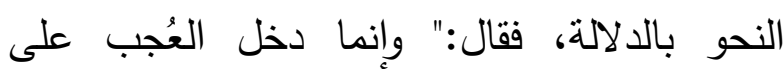
المنطقيين لظنهم أن المعاني لا تُعرف ولا تُستوضح

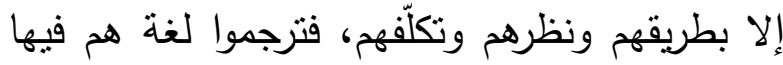

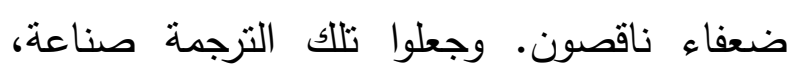

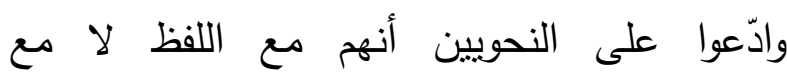
المعنى "2" وادعا

ومن هنا يظهر أن منهج النحاة الأوائل قد كان

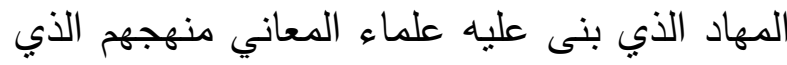

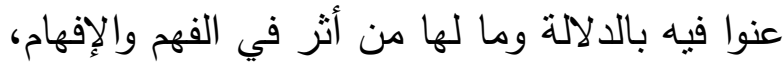

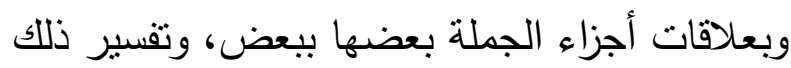

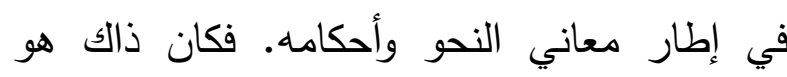
منهج النحاة قبل أن يختلف النحو على يد النحاة المتأخرين، وتتغير وجهته لتكون غايته كامنة في

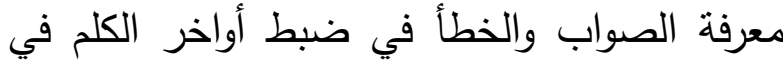
إطار فكرة العامل التي بالغوا فيها وفلسفوها، وألَّقوا

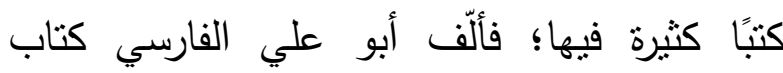
العوامل ومختصره، وألّف عبدالقاهر العوامل المائة.

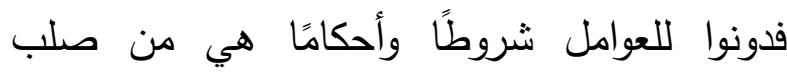

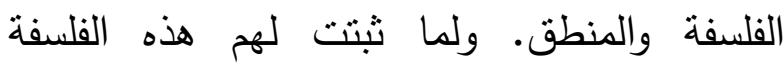

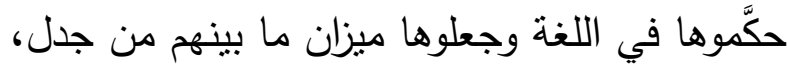

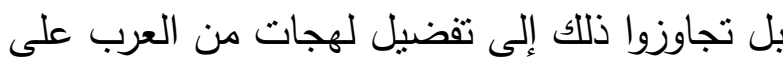

1 الأعلم الثنتمري، تحصيل عبن الذهب من معدن جوهر الأدب في لئي

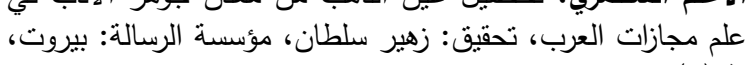

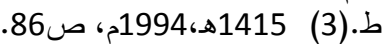

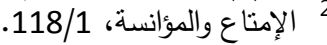




$$
\begin{aligned}
& \text { والمضارع. } \\
& \text { • الأفعال الخمسة. }
\end{aligned}
$$

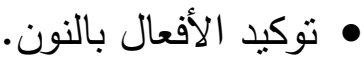

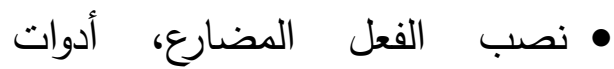

$$
\begin{aligned}
& \text { النصب ومواضع النصب بأن المضمرة النصارة }
\end{aligned}
$$

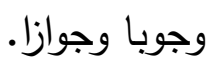

$$
\begin{aligned}
& \text { • جزم الفعل المضارع، أدوات الجزم } \\
& \text { للفعل الواحد، وأدوات جزم الفعلين. }
\end{aligned}
$$

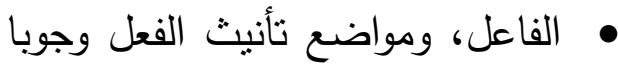

$$
\begin{aligned}
& \text { وجوازاً، وتقديمه على المفعول به ، أو تقديم } \\
& \text { المفعول به عليه وجوباً. } \\
& \text { • نائب الفاعل، والتغييرات التي تطرأ بأ } \\
& \text { على الفعل الصحيح والمعتل عند بنائه } \\
& \text { للمجهول } \\
& \text { • الاستثناء، بإلا - غير وسوى- خلا } \\
& \text { • الجمل التي لها محل من الإعراب }
\end{aligned}
$$

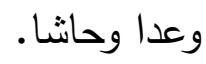

$$
\begin{aligned}
& \text { والجمل التي لا محل لها من الإعراب. } \\
& \text { • الحال، وصاحبها. } \\
& \text { موضوعات الصف الثالث الثانوي: } \\
& \text { • حروف الجر، أقسامها و والأصلي } \\
& \text { والزائد منها. } \\
& \text { • التعجب، وصيغتاه القياسيتان. } \\
& \text { منتهى الجموع. } \\
& \text { • المبتدأ والخبر، ومسائل الثقديم } \\
& \text { والتأخير أو الحذف في أحد عنصريه. } \\
& \text { وأخرى لفتحها. } \\
& \text { • • ل النافية الجنس. }
\end{aligned}
$$




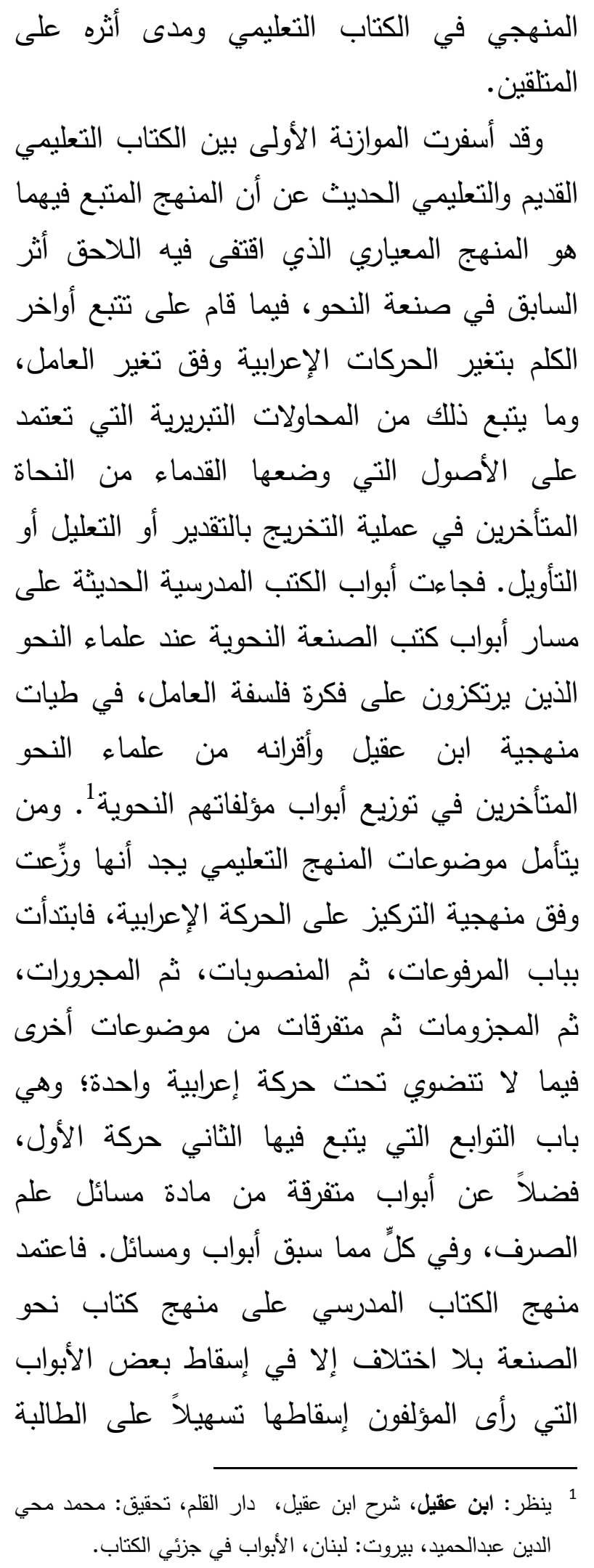

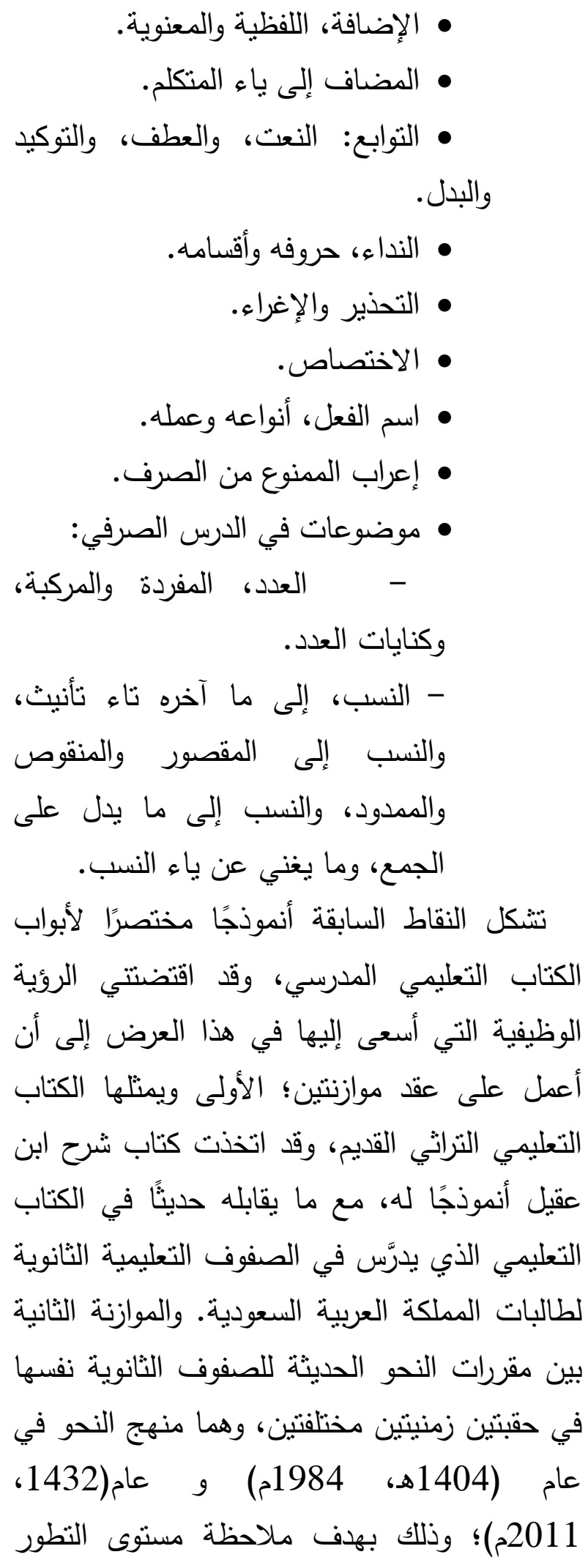


الأول إلى الثاني أو من الصف الثالث إلى : إلى

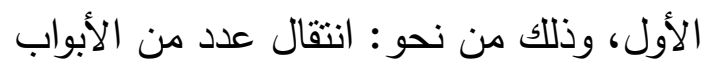

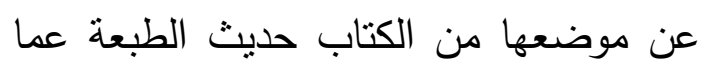
كان في الطبعة القديمة؛ كباب كان وأخواتها،

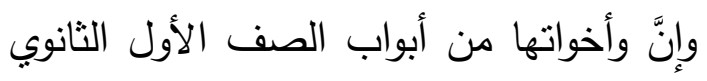

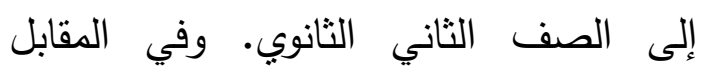
أضيف إلى الصف الأول موضوعات كانت

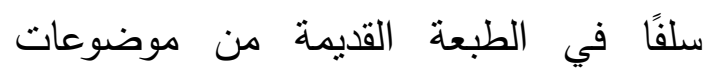
الصف الثالث وهي: تثثية المقصور والمنقوص موطنية

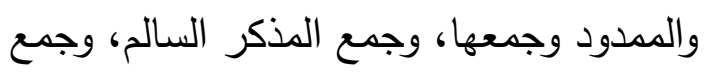

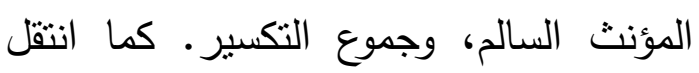
عدد كبير من الموضوعات في الكتاب حديث

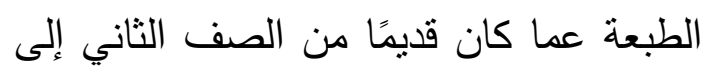

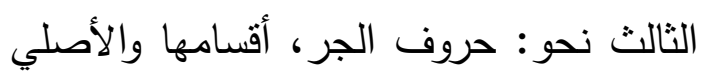
والزائد منها، الإضافة اللفظية والمعنوية،

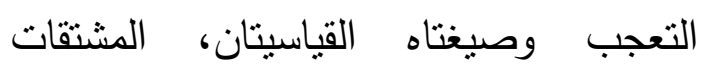

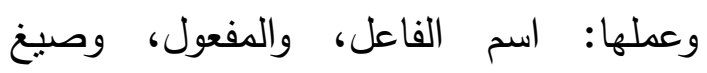

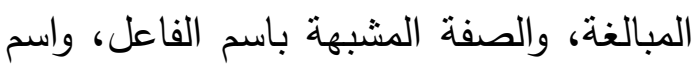

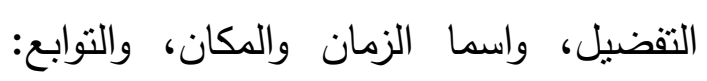

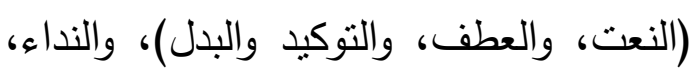

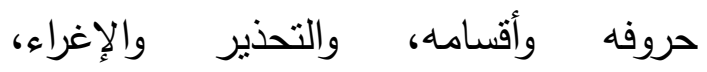
والاختصاص، واسم الفعل، أنواعه وعمله.

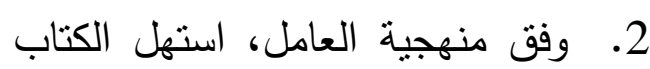
قديم الطبعة أبوابه بباب المرفوعات وجعل ونهل

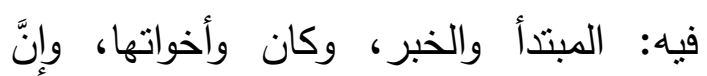
وأخواتها، ثم باب الفاعل، ونائب الفاعل. وفي واني واني

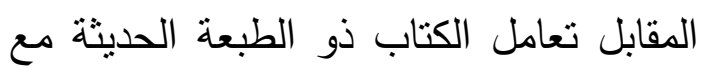
باب الفاعل ونائب الفاعل معاملة غير لئل
وانطلاقًا مما نادت به إحدى الدعوات التجديدية

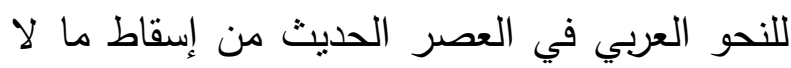

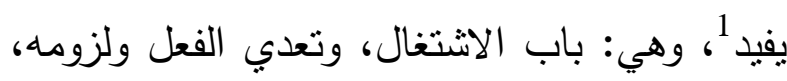

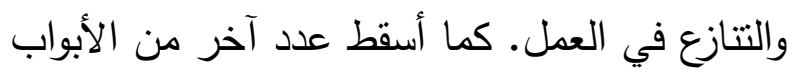
كالاستغاثة، والندبة، والترخيم، والحكاية، وأسماء الأصوات. مع إسقاط بعض الأبواب الصرفية، نحو :

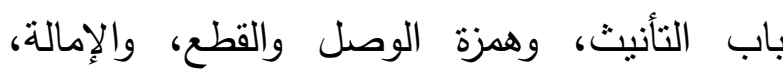
والوقف، والتصريف، والإبدال، والإدغام، والوقف.

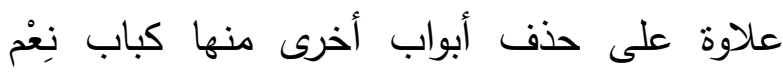
وبِنْس، وأبواب في المنصوبات؛ وهي باب: المفعول

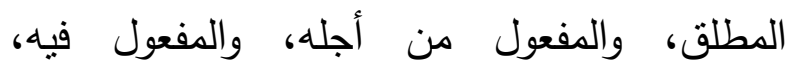
والمفعول معه، والتمييز . وهو إسقاط لا مبرر له، الهن

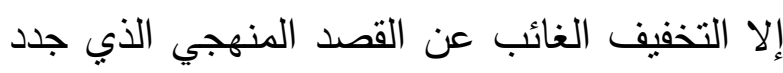
الموضوعات وأهمل الاكتساب المعرفي الثامل. وإذا نتبعنا منهجية الكتاب المدرسي الحديث في الاكي الحقبتين المختلفتين فيما حددنا طبعتهما سلفًا، نجد أن البون التاريخي بين الكتاب الأول والكتاب الثاني يُقََّّر بنحو سبعة وعشرين عائًا، وهي مدة كفيلة بأن الني

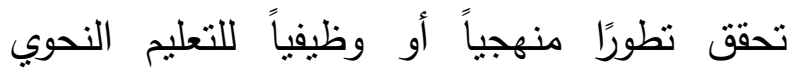
المدرسي. ولتعميق رؤية الموازنة بين المنهجين الحديثين يمكن ملاحظة الآتي:

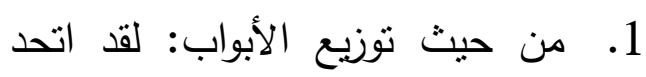

الكتابان في موضوعات الأبواب النحوية

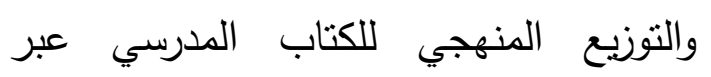

الصفوف الثانوية الثلاثة إلا في تغييري

بسيطة بنقل أبواب مما كانت في الصف

1 ينظر : عبد المتعال الصعيدي، النحو الجديد، دار الفكر العربي. 
4. التطور في العرض: استهلت الطبعة

الحديثة أبوابها في كتاب الصف الأول الثانوي

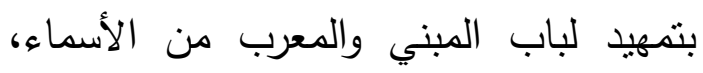

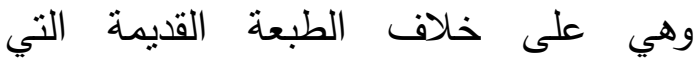
عرضت أحوال الاسم في البناء والإعراب دون

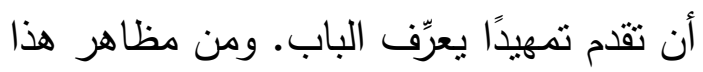
النطور في المنهج الحديث أيضًا أنه جمع كل هل ما يخص المعرب والمبني من الأسماء في

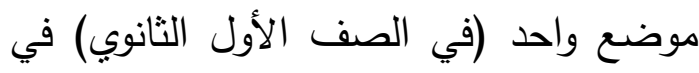
حين أن القديم فرق بينهما فجعلهما في

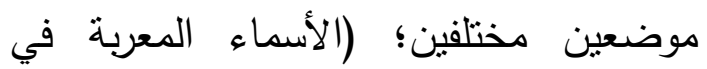
الصف الأول، والمبنيات في الصف الثاني).

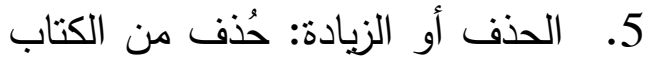
حديث الطبعة عدد من الأبواب؛ وهي: باب

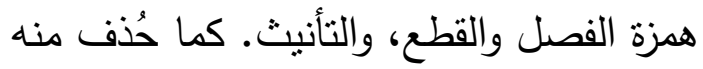

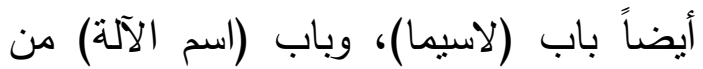

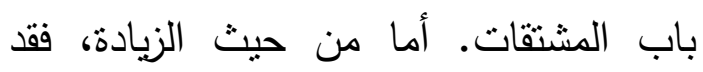
زيدت في المنهج الحديث بعض الموضوعات التي لم تكن في منهج الطبعة القديمة؛ نحو :(لا) النافية للجنس، وظن وأخواتها. 6. اء في آخر الكتاب القديم مسائل وطن من أبواب الصرف، فظهر الكتاب مقسومًا إلى في ألى جزأين: أحدهما، النحو؛ ويتضمن أبواب الصف الأول والثاني ومستهل الصف الثالث. والثاني، الصرف؛ ويتضمن الأبواب الأخيرة من مسائل كتاب الصف الثالث. في حين نجد الثد موضوعات الصرف في الكتاب الحديث
معيارية أو بعبارة أخرى غير عاملية، فجعلهما في باب آخر غير باب المرفوعات، وأدخلهما

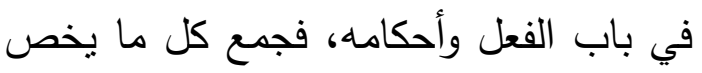

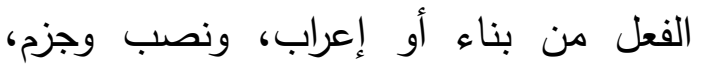
وتوكيد وتأنيث في موضع واحد، وربط هذه

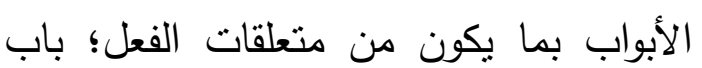

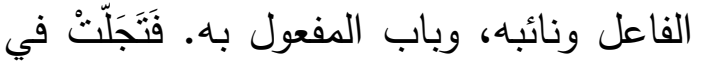
الكتاب منهجية وظيفية نعاملت مع الجملة بشكلها التكاملي؛ أب الفعل الذي هو بؤية نعامة

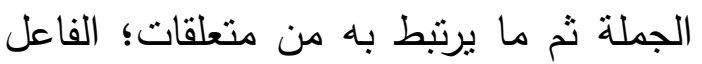

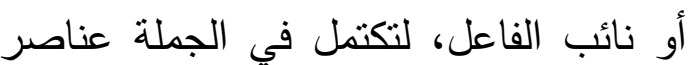

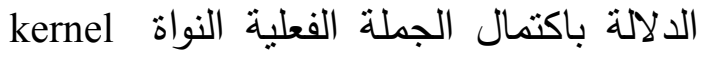

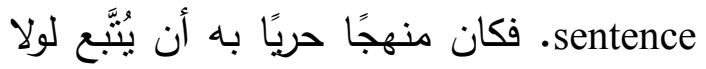

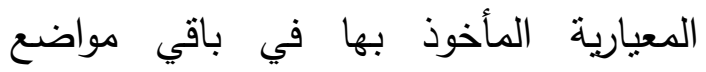
الكتاب.

3. التزم الكتاب المدرسي القديم بمنهجية

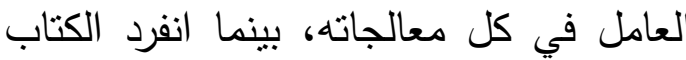

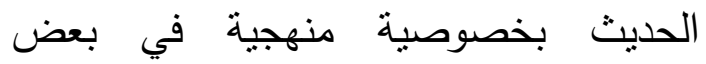

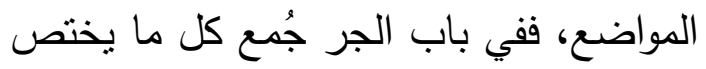

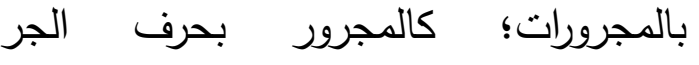
والمجرور بالإضافة. وهي بادرة تجديدية لولا

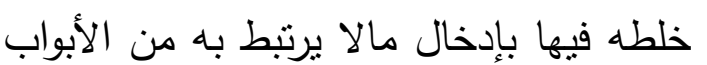

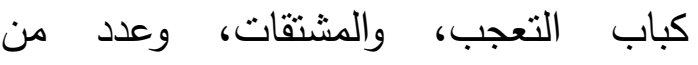

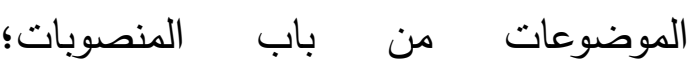
كالاستثاء، والنداء، والتحذير، والإغراء، والاختصاص. فكان تداخلا لا مبرر لله غير والاءعراء الخلط المنهجي. 


$$
\begin{aligned}
& \text { موزعاً بين مسائل الصف الأول والصف الحركة الإعرابي، ويمكن أن نلمس ذلك من خلا }
\end{aligned}
$$

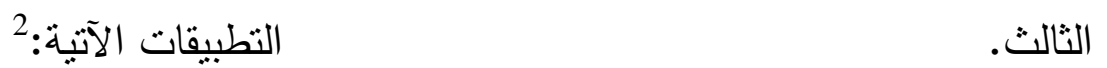

$$
\begin{aligned}
& \text { • ( م أعرب ما تحته خط. }
\end{aligned}
$$

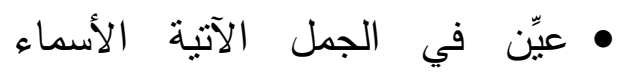

$$
\begin{aligned}
& \text { المرفوعة(أو المنصوبة أو المجرورة) وبيِّن }
\end{aligned}
$$

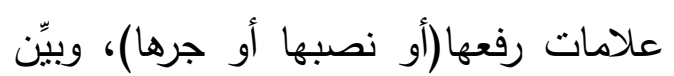

$$
\begin{aligned}
& \text { رافعها (أو ناصبها أو جارها). }
\end{aligned}
$$

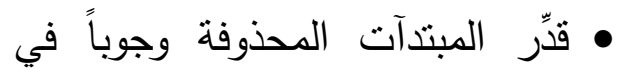

$$
\begin{aligned}
& \text { القطعة التالية، وبيِّن علة حذفها. }
\end{aligned}
$$

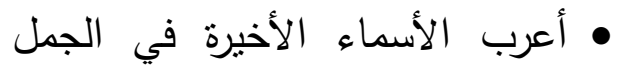

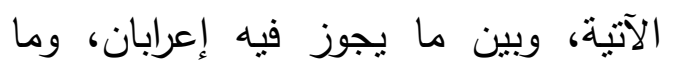

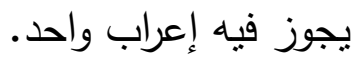

$$
\begin{aligned}
& \text { • ميّز الأفعال الناقصة من الأبه الأفعال }
\end{aligned}
$$

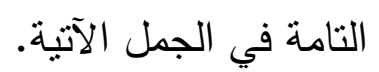

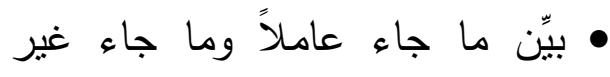

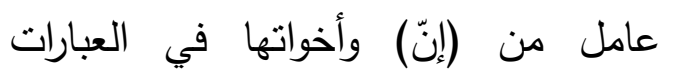

$$
\begin{aligned}
& \text { الآتية، ووضح سبب الإلغاء فيما لم يعمل فئل } \\
& \text { منها. } \\
& \text { • ادخل (ما) الزائدة على (إنّ) وأخواتها }
\end{aligned}
$$

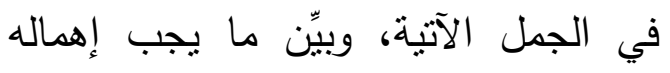

$$
\begin{aligned}
& \text { منها وما يجوز • } \\
& \text { • بيّن أوجه الإعراب في الاسم الذي } \\
& \text { بعد(لاسيما) في الجمل الآتية، مع تعليل } \\
& \text { كل وجه. } \\
& \text { • أعيّن معمول المصدر فيما يأني، ثم وجنه }
\end{aligned}
$$

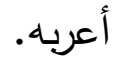

$$
\begin{aligned}
& 2 \text { ينظر : كتاب النحو والصرف-بنات- المملكة العربية السعودية، وزارة } \\
& \text { التعليم العالي، ط(1984)، ط.2011م. } \\
& \text { وهكذا، وبعد النظر والموازنة بين المنهجين، في }
\end{aligned}
$$

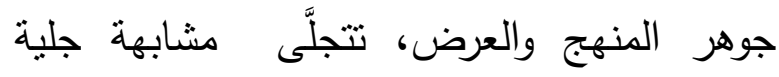

$$
\begin{aligned}
& \text { بينهما إلا في اختلافات طفيفة لا تعدو الاختلاف }
\end{aligned}
$$

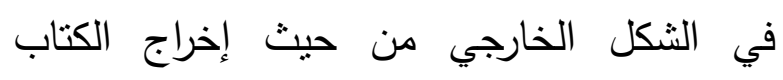

$$
\begin{aligned}
& \text { وألوانه، أو في انتقاء خطوطه وصور العرض. }
\end{aligned}
$$

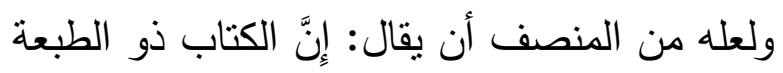

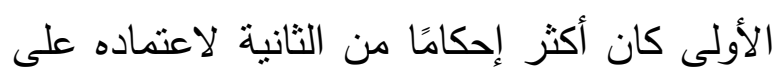

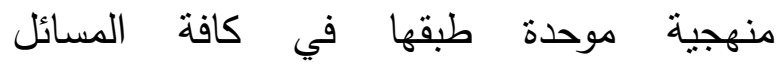

$$
\begin{aligned}
& \text { والموضوعات فيما قد غابت عن الكتاب الحديث، } \\
& \text { وقد كان من اللافت مع هذه المسافة الزمنية بين }
\end{aligned}
$$

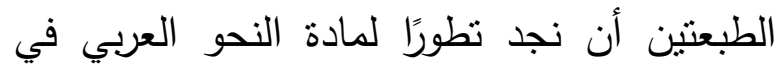

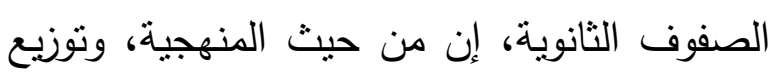

$$
\begin{aligned}
& \text { الأبواب، وتتاول النصوص أو ربما في التدريبات، } \\
& \text { بل حتى على مستوى الإخراج الفني، ولاسيما وأن }
\end{aligned}
$$

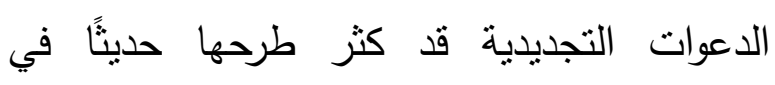

$$
\begin{aligned}
& \text { الساحة في ظل الدعوة إلى التجديد المنهجي في } \\
& \text { تعليم النحو العربي } 1 .
\end{aligned}
$$


بعطلية الاختزال والاختصار فتلنغى أو تُختصر

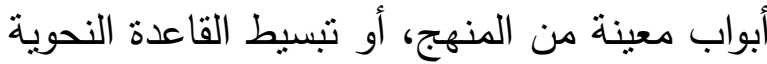

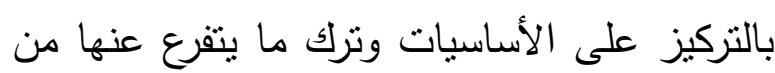
وبإنعام النظر في النطبيقات أعلاها نجد أنها

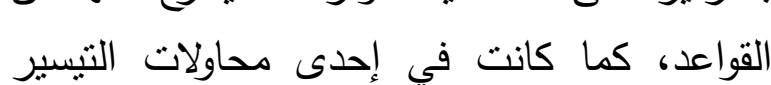

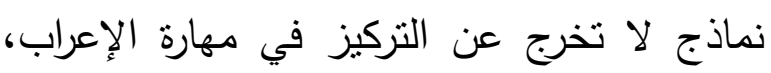

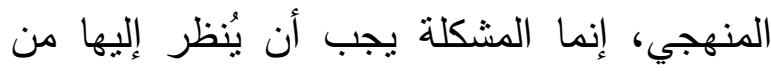

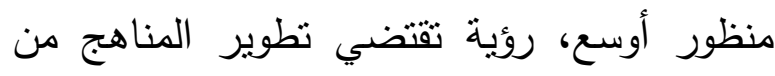

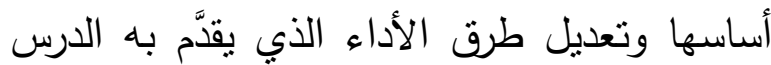

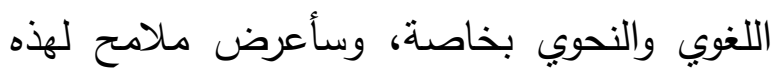
التصورات في الصفحات القادمة من هذا البحث.

$$
\begin{aligned}
& \text { توصيات في المنهج التعليمي } \\
& \text { تعددت التوصيات في الدرس الحديث حول الدئي } \\
& \text { معالجة المعيارية في كتاب النحو المدرسي، وتباينت } \\
& \text { اتجاهات أربابها في المنهج المتبع في إحداث }
\end{aligned}
$$

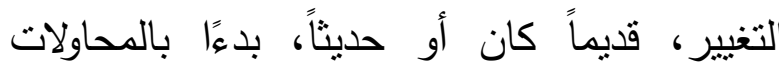

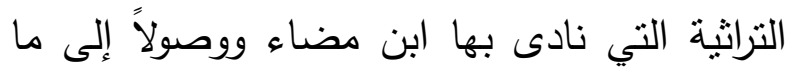

$$
\begin{aligned}
& \text { هو غاية الأطروحات البحثية في عملية الإصلاح }
\end{aligned}
$$

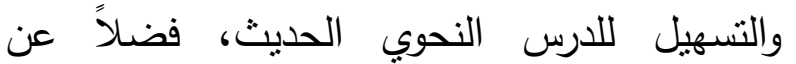

$$
\begin{aligned}
& \text { الهاجس الذي يقبع في نفس كل معلم أو مربٍٍ. } \\
& \text { وسنقام في هذه الصفحات بعض التصورات والرؤى فئى } \\
& \text { الخاصة بعملية تقويم منهجية الكتاب المدرسي } \\
& \text { للطلاب والطالبات الناشئين والناشئات من المتعلمين الكين }
\end{aligned}
$$

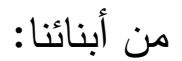

$$
\begin{aligned}
& \text { تأني في مستهل هذه الروئى فكرة باتت ملحة في أنيا } \\
& \text { أعماقنا الفكرية، تقتضي ضرورة إعادة النظر في الني } \\
& \text { النحو العربي وفق وظيفته الأولى التي عرَفها عنه أعنه } \\
& \text { علماء العربية الأوائل، والذي عرّفه ابن جني بأنه: }
\end{aligned}
$$

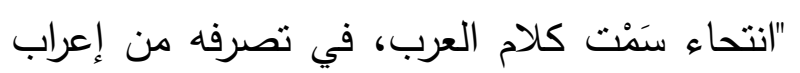$$
\text { والبحث عن العامل، تاركة وراءها جانباً لا نراه }
$$

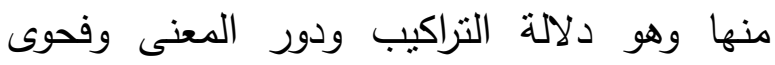

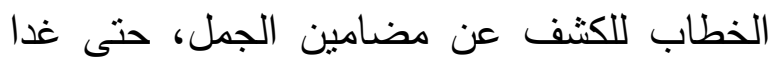

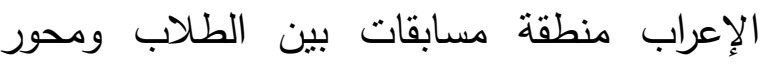$$
\text { هيكلة الدرس النحوي. فأغفلت هذه الدنهية الطنابة }
$$$$
\text { التعليمية المعايير التفسبرية الأخرى؛ البنيوية، }
$$

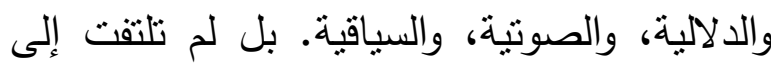$$
\text { الركيزة الأساسية في ماهية النحو وهي النظر في }
$$$$
\text { الجمل وفق مفهوم التطليق في إطار العلاقات }
$$

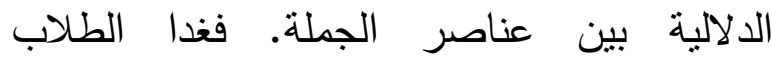$$
\text { والطالبات يعرفون من النحو الإعراب، ويرتكزون }
$$

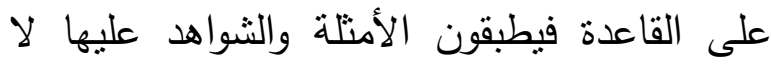$$
\text { العكس، وكأن القاعدة هي الأصل والثواهد العربية }
$$$$
\text { قائمة عليها. ولا يخفى أن هذه القواعد المعيارية }
$$

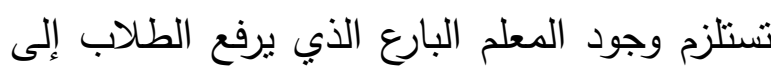

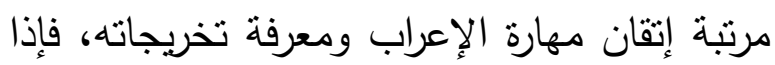
واجه الطلاب معلمين ماهرين في تنريس النحو الإنداب كانت لهم أرضية صلبة يققون عليها، فيتأسسون في مادة النحو وييدعون في الإعراب الذي يروني لئه

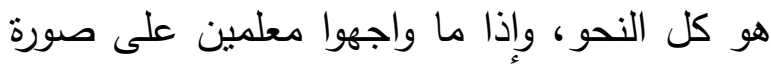
معاكسة، أعني ضعفاء في ميدانهم، شعر الطلاب بعسر النحو ومن ثم مقتوه ولاذوا بالفرار منه. فينبري عن هذا الضعف والنفور مشكلة تعليمية تقتضي الوقوف عليها والتماس حلول لها، إلا أن

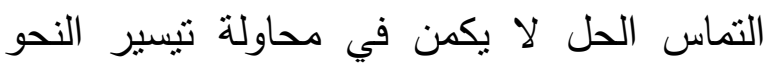


في شكلها الترتيبي والتركيبي. والثاني، دلالي يتأمل المعاني التي أضافتها تلك الظواهر إلى الجملة في تركيبها الأصل. فتكون دراسة النحو في إطار مفهوم

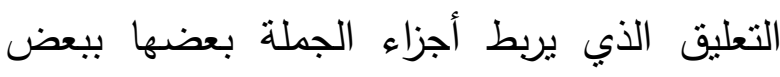

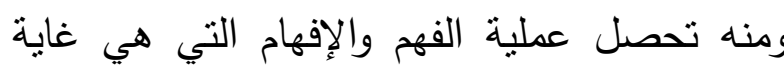
اللغة، ولا يخفى أن فكرة التعليق هذه قائمة على ولى تضام القرائن كلها؛ اللفظية، والمعنوية، والمقالية. وهي الفكرة التي نادى بها عالم اللغة الحديث تمام حسان وتبعه فيها محمد حماسة عبداللطيف وغيره ممن كانوا ينادون بإصلاح النحو العربي وربط المباني بالمعاني في معائواندة باصنا الجمل وتحليل

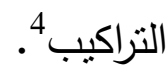

وفي هذا الإطار يمكن أن نؤصل منهجيات تعليمية حديثة تقوم على نطوير النحو ليتجاوز

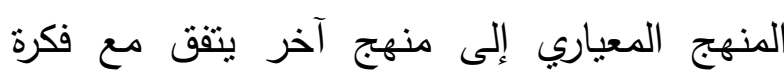

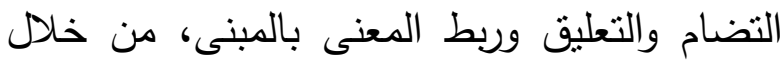

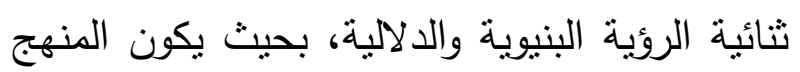

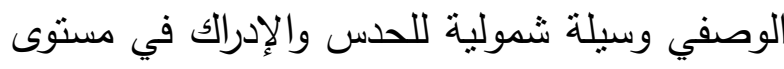
التعليم اللغوي، فيكون تطبيقه على اللسانيات العربية مفيدًا في تخطي منطقة العسر التي تكمن في لتئي المسائل التي تبنى على القول بالتأويل والتقدير والتعليل، وذللك بإعادة النظر في الثواهد التي أسِّ

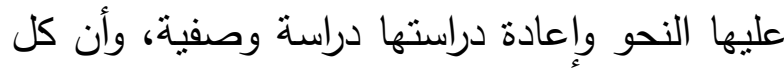
شاهد منها وجه صحيح للعربية، وأن كلاً منها يمنل واعلة وان دران " ينظر: تمام حسان، اللغة العربية معناها ومبناها، الهيئة المصرية

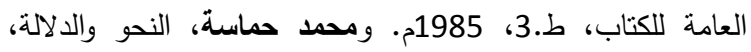

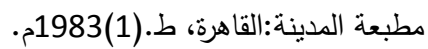

وغيره" . والذي عرّفه السكاكي بأنه"معرفة كيفية

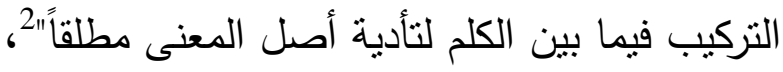

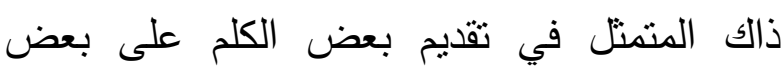

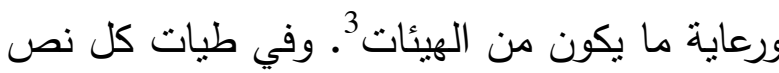

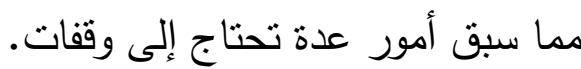

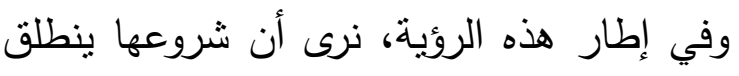

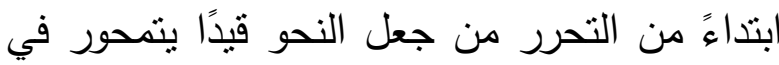

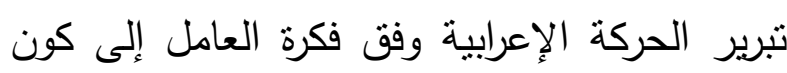

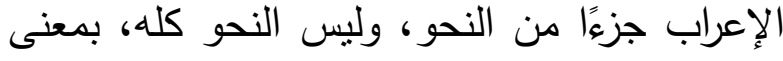

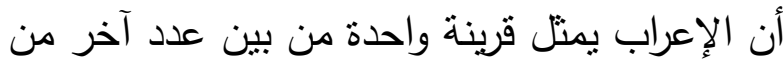
القرائن التي يجب أن يُعنى بها وتؤخذ في الحسبان وندان

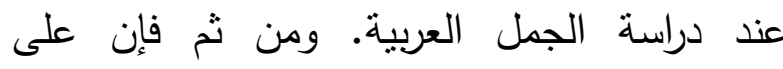
المناهج الحديثة أن تأخذ بعين الاعتبار فكرة تلازم

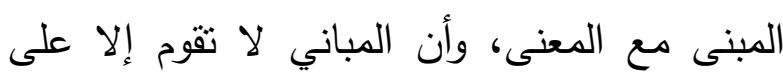

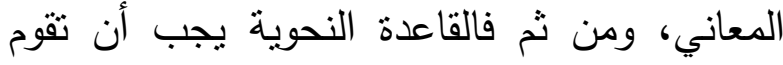
على مستويي المبنى والمعنى معاً؛ لأن معالجة التراكيب وفق المباني وحدها يحرم الدارس المتعلم من حق آخر يستجلي به معاني الجمل واختلاف أوضاعها. فيعمل هذا الربط على طرح لهن منهجية

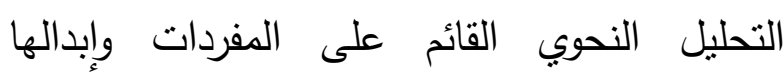
بالتحليل القائم على الجمل، أو بعبارة أخرى نعمل

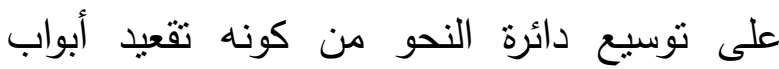
مفردات إلى تقعيد أوسع في إطار الجملة، فيتم تدريس التقديم والتأخير، والحذف، والزيادة ...الخ في إن

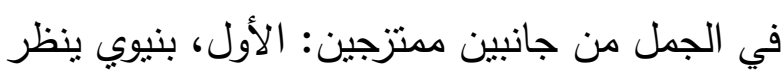
الخصائص،34/1. 2 السكاكي، مفتاح العلوم، دار الكتب العلمية:بيروت،لبنان، ص75.

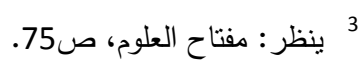


وتتغير هوية كثير من الألفاظ عما صُنِّقت فيه، بل ستلغى أبواب نحوية بأكملها.

ولو أردنا أن نضع تصورًا مبدئياً لهذه المنهجية،

فإننا نجد أن الأبواب سنقوم على منهجية تكاملية تعليقية جملية لا مفردية أو حركية عواملية كما كان

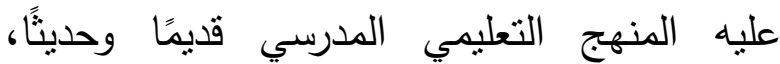
فتُصنَّف الأبواب وفق مفهوم التأثنير والتأثز الدلالي ولئي

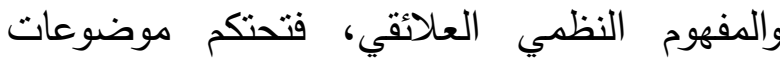
الباب الواحد على ما تجتمع عليه من مسائل دلالية؛

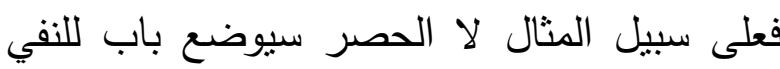

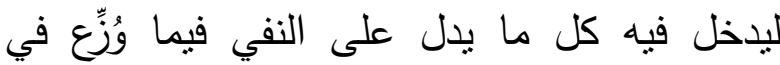
أبواب متفرقة من أبواب منهج العامل، فيكون منه

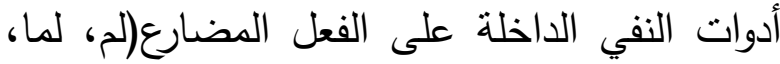

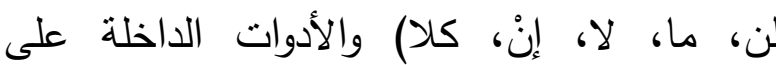

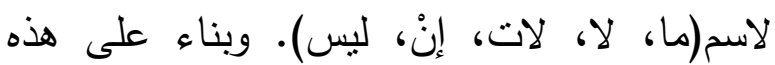

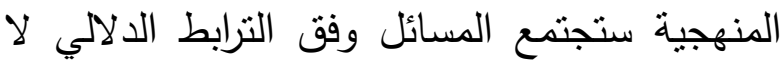
غير، فكان من نتائج الدلالة في هذا الباب أن

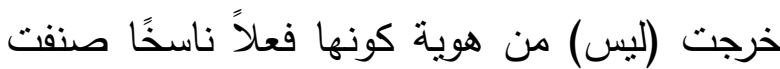
في مصاف الفعل الجامد احتكامًا إلى عملها الذي لهاي

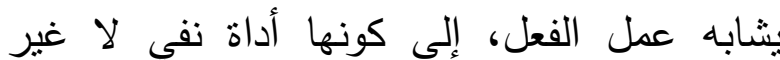

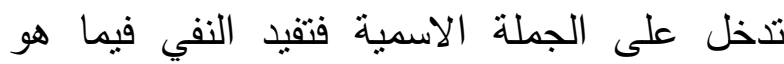

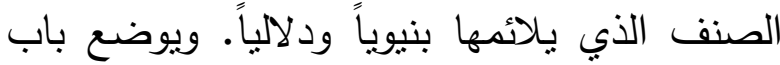
آخر في التوكيد ويدخل فيه كل ما يفيد التوكيد دلالباً، دون الالتفات إلى الحكم المعياري في الأثر

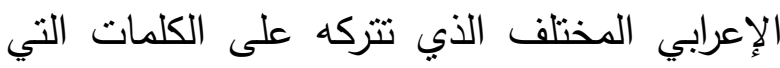
تدخل عليها، فيندرج في هذا الباب مسائل عديدة، منها: باب التوكيد اللفظي والمعنوي، والأدوات التي هلي
حجة وإن خالف الكثرة، مع توظيف الثواهد في اللغة الحية في جوها المعاصر لتحقيق الفهم اللغوي

$$
\text { للمتلقي الحديث. }
$$

وبناء على هذا الربط بين المعنى والمبنى، يجب

إعادة النظر في أبواب الكتاب النحوي بحيث يخرج التبويب في الكتاب المدرسي عن المعيارية وفكرة التأثثر والتأثز في إطار العامل والمعدول والحركة عندي الإعرابية إلى أفق أرحب وفضاء لغوي أنثمل،

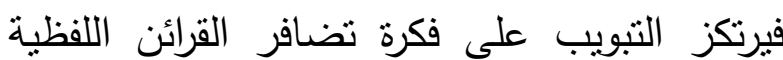
والدلالية والسياقية، وعلى مفهوم النظم والتعليق، لئل

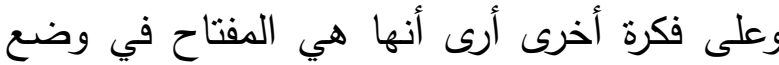
تخطبط جديد للمنهية فيما أصطلح على تسميته بـ(نحو المعنى)، ويتطلب هذا التخطيط محاولة نفث خيوط علم المعاني البلاغي لإعادة غزلها في نسيج متكامل مع مضامين النحو، ليكوّنا معًا كيانًا واحدًا، عودًا إلى أصل النحو في زمن أرى أنه كان يمثل النضج الفهمي للغة، فيكون النحو بهذا الامتزاج هو النهو النه انتحاء سمت العرب في لغتهم المعبرة عن معاني

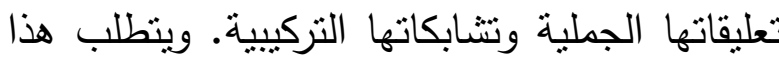
النسيج الخيطي المتضافر جسدًا يتلاءم معه وتبويبًا يرتكز عليه، يتمثل من المادنين معًا، وأعني بهما:

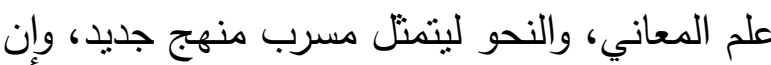

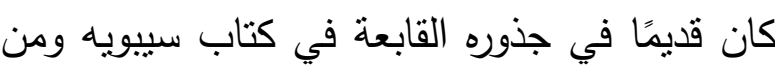

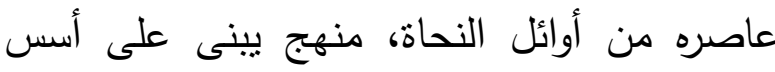

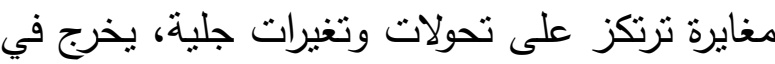

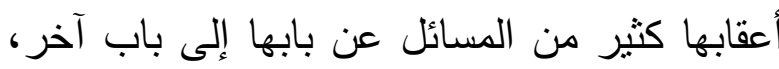


المعاصرة خاصة، فعلينا الانتقال من التحفيظ

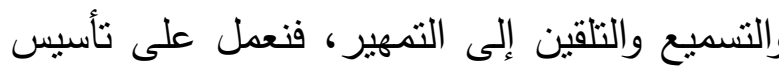
مهارات حديثة تتهض على تفعيل دور الذات

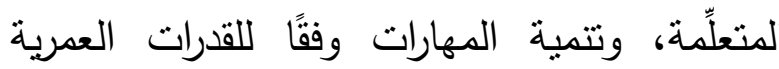

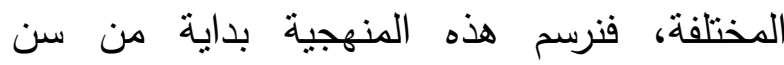

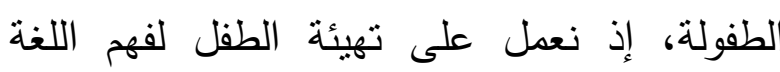

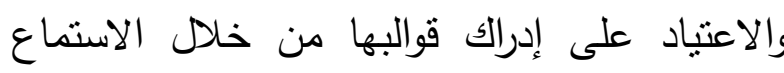
للقراءة الصحيحة بوسائل تعليمية ترفيهية؛ (سواء

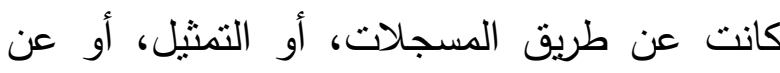
طريق الألعاب اللغوية)، أو باستخدام تقنيات تربوية في إطار برامج خاصة بالأطفال منجزة بلغة عربية

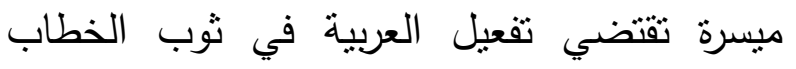
العربي المعاصر الذي يعبر عن مدلول الخطاب في في في لفي أفكار أهله وأهدافهم لا لغته في أصل وجودها غير دالهير

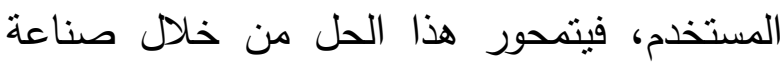
السليقة اللغوية التي هي أساس اللغة وعماد رفعتها، فيكون هذا هو المرحلة الأولى، ومن ثم يكون التدرج

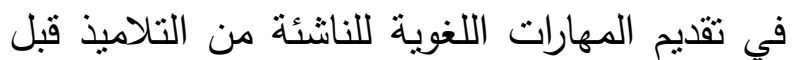
تعليمهم المصطلحات النحوية في مراحل مبكرة، إذ

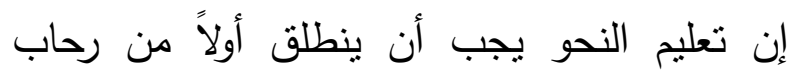

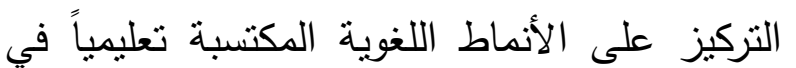
المراحل الأولى، ليتحقق للمتعلمين الصغار لسانًا

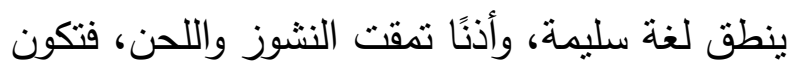
هذه المرحلة هي التي تقود إلى فهم القواعد النحوية، فيتلاشى هاجس الإحساس بصعوبة النحو والنفور

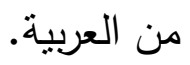

تدخل على الجملة الاسمية فتقيد التوكيد، نحو : (أنَّ، إنَّ، إنما، لكن، بل) والأدوات التوكيدية التي تدخل التهل

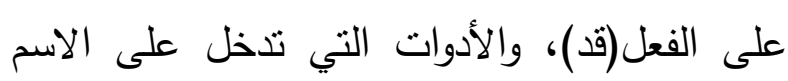
والفعل وهما (اللام والقسم). كما يمكن أن يدخل في لادول

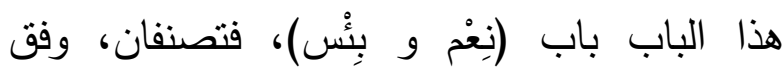

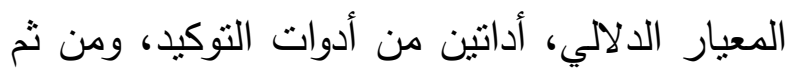
تخرجان عما وضع لهما معياريّا كونهما أفعالاً جامدة احتكامًا إلى الأثر الإعرابي الذي تثركه على على

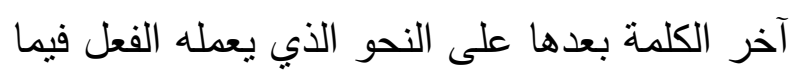

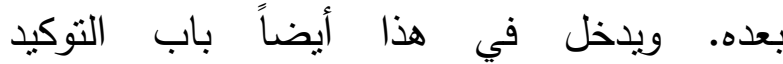

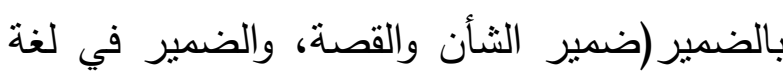
أكلوني البراغيث). كما يمكن أن نضع بابًا منفردًا في التقديم والتأخير ليشمل كل ما تقبل جملته تغييرًا

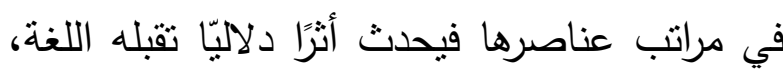
فيندرج فيه مسائله الموزعة في الأبواب؛ باب تقديم

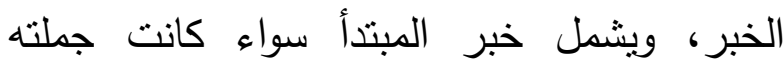
إخبارية أو توكيدية بتصدر (إنَّ أو أنَّ) على جملته، كاء كانَ

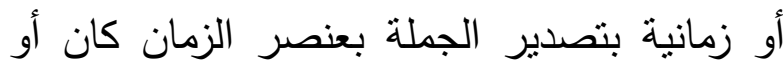
بات أو أصبح...الخ، أو تقديم المفعول أوغير ذلك. بلك. وباب آخر في الفصل والوصل ويدخل فيه

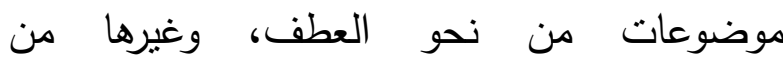
التفصيلات التي ننوي أن نتمها في بحث مستقل.

وفي إطار هذه الرؤى أيضًا، يجب أن تتخطى

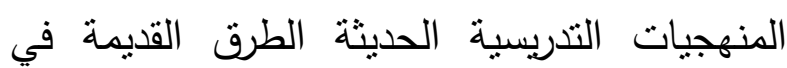
التدريس، فيما كانت قوالب غير مناسبة للأجيال 
المعاني التي فهمها من خلال تسجيل مناقتته وتمييز لغته عبر هذه التسجيلات.

وللمختبرات اللغوية أهميتها في جوانب أخرى من

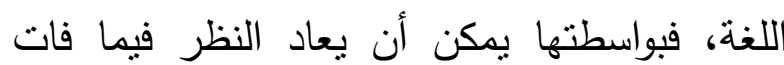

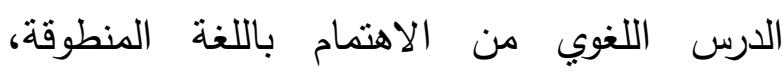

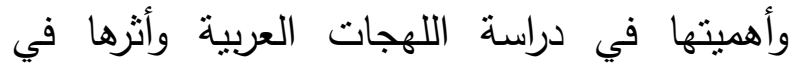
معرفة تاريخ اللغة، علاوة على دورها في الكثف الثفات

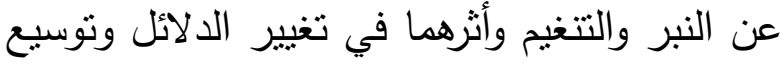
نطاق التعبير عن المعاني الإنسانية التي تعجز عن

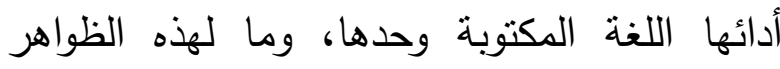
الصوتية من أثر في تيسير النحو بحذف عدد من وحنا،

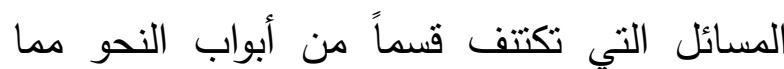
كانت تقوم مقامها اللغة المنطوقة، من نحو القول

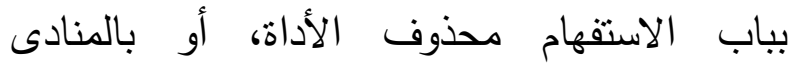
محذوف الأداة... وغير ذلك.

ويتمخ عن الرؤية السابقة حلول منهجية أخرى تقتضي خلق جو من تعليم العربية على ضوء التوظيف الأدبي فيما يعنى به علم اللغة الوظيفي نعيم لفئي

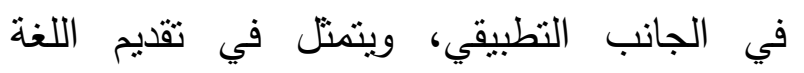

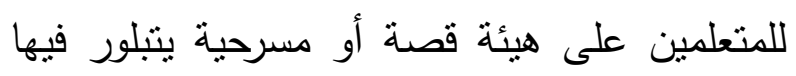
الأداء اللغوي من خلال توظيف الحوار الأدبي

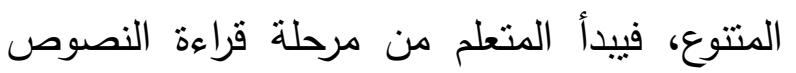

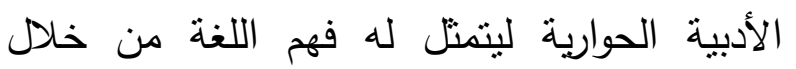
نظمها التركيبي التطبيقي، فيرتقي فهمه للغة، وتتمو لهون لهن

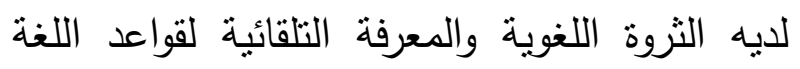
العربية، وتتضح له الصورة الصحيحة للنطق
ويتعاضد مع الحل السابق، السعي وراء تقعيل

دور المختبرات الصوتية أو اللغوية في عملية التدريس، وجعلها أول أسس التعليم منذ المراحل التعليمية الابتدائية، فتستخدم لتحقيق مهارات: الاستماع، والترديد، والتسجيل. فيستمع التلميذ أولاً في المراحل الدراسية الأولى لئى إلى نصوص مسموعة تمنحه معرفة القراءة

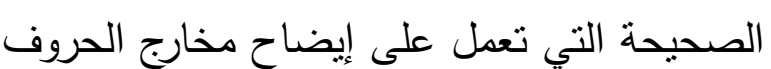

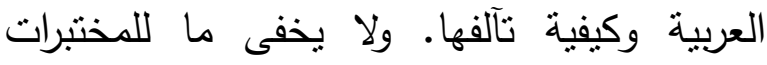
اللغوية من دور رائد في تذليل صعوبات النطق

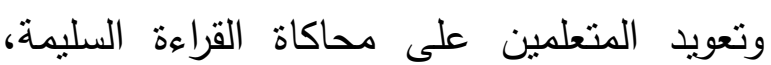
علاوة على أهميتها في معالجة كثير من عيوب النطق التي قامت على علاجها اليوم معاهد متعددة خارج الدوائر الرسمية للتعليم. عالتهي

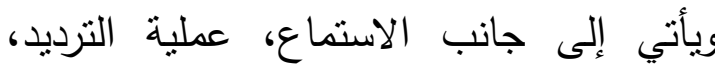
فيردد الطالب الجمل والتراكيب في النص الذي استمع إليه، ومن ثم يعمل الجهاز على متابعة لغته، فيطلق عبارات تعليقية مختلفة؛ فيعقب لئب بأسلوب تشجيعي على مواطن الصحة في الإلقاء،

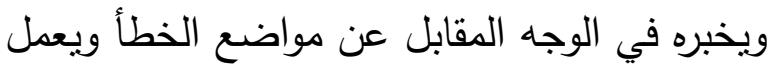
على تصويبها. وتأتي بعد ذلك مرحلة التسجيل؛ وذلك بتسجيل نصوص مختلفة؛ شعرية، أو نثرية في موضوعات مختلفة بغية تعويد الطالب على تمييز المعاني

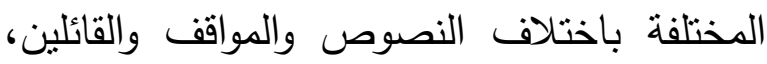
فيتسنى له فهم المعاني واستخلاص الفكرة الأساسية والأفكار الفرعية، ومن ثم يؤتى الفرصة للتعبير عن لن 
دلالي بعيداً عن حفظ كلمات مفردة مجردة تجعل

$$
\text { الدارس يكاد لا يحسن استخدامها"2. }
$$

ومن تلك الحلول المنهجية في تدريس اللغة

العربية ونحوها أيضًا، تشخير معطيات تكنولوجيا

العصر للأخذ بيد القائمين عليها لتأسيس منهجيات فئنسات

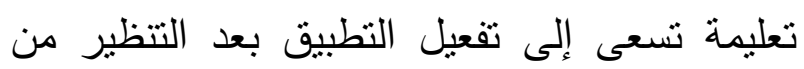

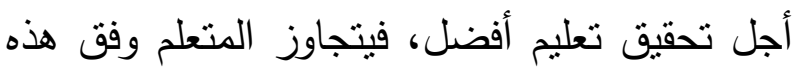

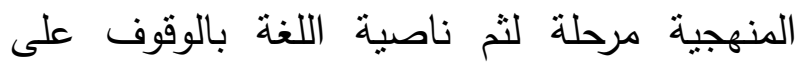

الأمثلة المكرورة في تعليم العربية، واللغة من أبرز

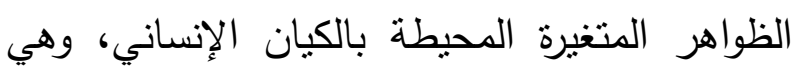

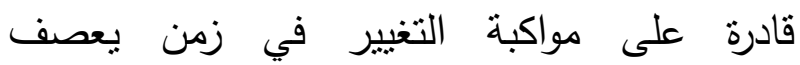

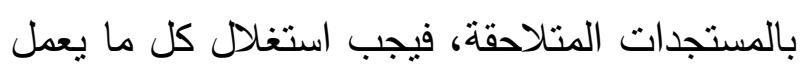

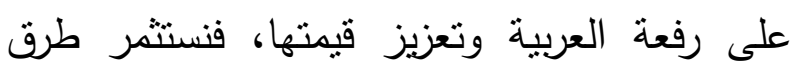

التعليم الآلي؛ كأساليب التعليم الذاتي، والتعليم

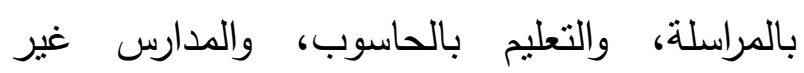

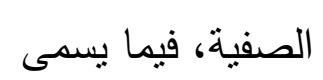

E-Learning: Online Education, Web

.Based Education, Electronic Education

ويمكن أن يستعان بتلك الآليات الحديثة لإنشاء

قاعدة أساسية يتكئ عليها في التوضيح والثرح

للطلبة، كأن نعمل على وضع برامج توضيحية تعد

من خلال النظم الإلكترونية تتضمن:

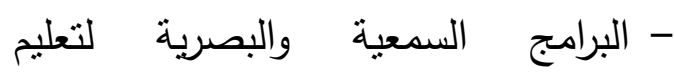

الأصوات العربية؛ مخارجها، وصفاتها،

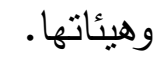

$$
\begin{aligned}
& \text { " عبدالله العطاس، دراسات في التوظيف المسرحي، مطبوعات نادي }
\end{aligned}
$$

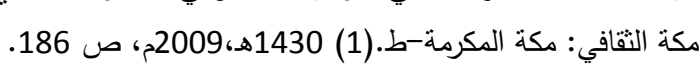

اللغوي، ويعي مفهوم تتوع الدلالة في التلونات

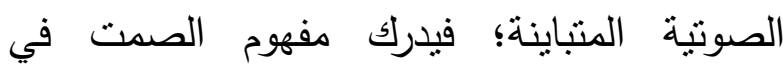
الموقف الذي يقتضيه خلاف موقف الكلام، ومفهوم الأداء الصوتي للفخر، أو التعجب، أو الاستقهام

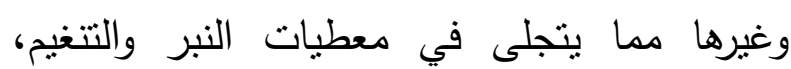
فضلاً عن تلمس التغييرات في نمطية الجملة

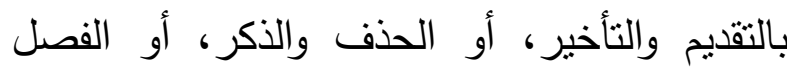
وغيرها من الظواهر اللغوية التي يستقيها المتعلم من تفقد وظيفتها الطبيعية في البيئة المنطوقة بها، فيتحرز من أخذ اللغة من خلال حفظ المفردات وتتكيل أواخرها فيما تعوق المتعلم من فهم معناها

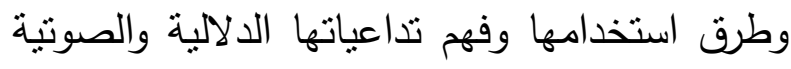
والتركيبية. وتعد هذه الحوارية من أبرز الأسس التي

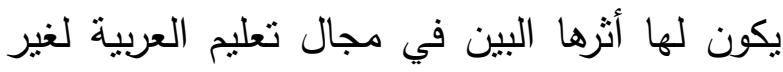

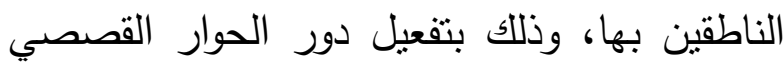
والمسرحي بلغة عربية معاصرة، فيما كان له نتائج

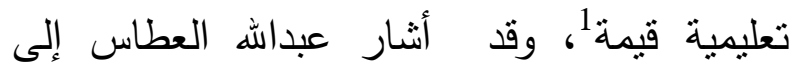
أهمية الحوار القصصي في تعليم العربية لغير وفي

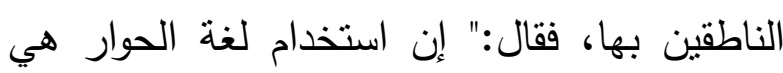
أنسب الطرق الحديثة لتعلم اللغة الهدف، وهي لفي طريقة أثنتت فاعليتها الناجعة في هذا المجال(مجال

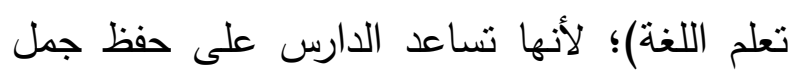
تامة كاملة، وإن كانت بسيطة ميسرة، لها معنى لهاعل

$$
\begin{aligned}
& 1 \text { وقد عملت بهذا المشروع كمساعد للدكتور أحمد مليباري أستاذ اللغة } \\
& \text { في جامعة نوتتجهام، وقد كان البرنامج باسم: } \\
& \text { Arabic for business e-learning project- King's College- } \\
& \text { London-Modern Language Centre-16 -July } 2010 .
\end{aligned}
$$


الطموحة إلى المستقبل. فإذا كانت اللغة خير وسيلة لهذا التعريف فما أخطر اللغة إذاً ؟ "1.

$1{ }^{1}$ تمام حسان، مناهج البحث في اللغة، دار الثقافة: الدار البيضاء،

1986م، ص11.
- برامج أخرى للصرف الآلي الذي يقوم

على تحليل الكلمة إلى عناصرها الاشتقاقية والتصريفية. - برامج للتنقيق الإملائي. - برامج للإعراب الآلي الذي يحدد المواقع لإنع وفق آليات بنيوية ودلالية.

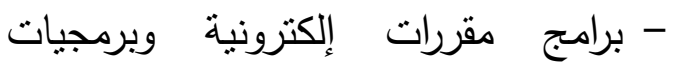

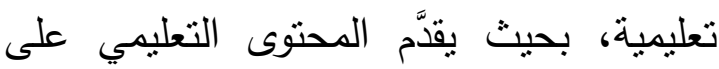
أقراص مدمجة أو في شكل صفحات تعتمد

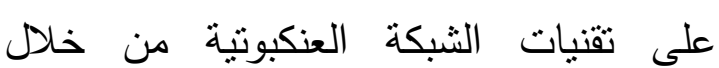
مجموعة من الوسائط المتعددة والمتمنلة في: هي: النص، والصوت، والفيديو، والرسوم الثابتة

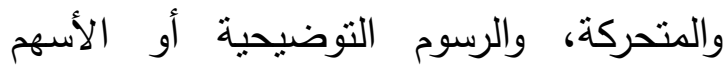
التشجيرية وغيرها. فضلاً عن إدخال الترفيه بالتعليم والعمل على استعمال الألعاب اللغوية في العملية التعليميةعلى النحو الذي نراه منبعاً في اللغات الأجنيية الأخرى. فتعمل هذه الآليات على الأخذ بيد العربية الآنية

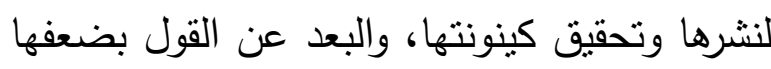
أو صعوبتها، ويحسن بي في هذا الصدد أن أنقل

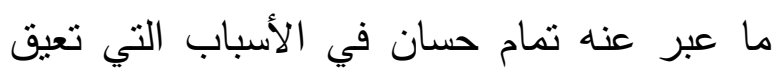
تطور العربية، فقال:"إن أكثر الأمم جلباً للأصدقاء الأ فيأ هي تلك التي تعمل على تعريف الأمم الأخرى بها، سواء في ماضيها أو في حاضرها أو في آمالها 
2. إن المبنى والمعنى وجهان لعملة

واحدة، وأن توظيف تشابكهما هو معيار

المنهجية التقعيدية السليمة.

3. يتطلب وضع الخطط والمنهجيات

كفاءة علمية متخصصة، وأن يوضع في

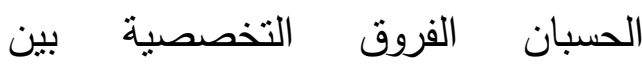

الأكاديميين الخبراء في اللغة وعلومها،

وبين تلك الشرائح التي تأخذ اللغة تعليماً

بصفتها الاكتسابية.

4. تكثيف النظر لنطوير التهنه المناهج

التعليمة في المراحل التعليمة المختلفة

بصورة علمية مستمرة، ومنهجية تكاملية.

5. البعد عن الفلسفة الجدلية في تعليم

اللغة العربية والتركيز على الروئة الدلالية

والمنهجية الوصفية التأملية.

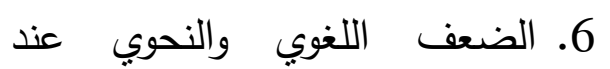

المتعلمين منبعث من غياب المنهج

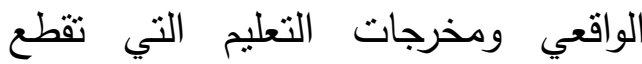
الصلة بين النظرية والتطبيق.

7. يجب أن يعتمد تعليم اللغة على بلى ولئي

تطوير المهارات الأساسية فيها من كتابة،

وقراءة، وسماع، ومحادثة بصورة شمولية.

8. تتويع مخرجات التعليم بتفعيل دور

الفهم التركيبي النظمي، والأداء الصوتي، لتوني

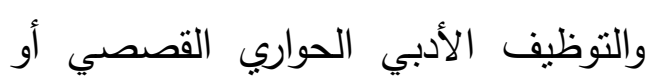

المسرحي....وغيرها.

9. الإفادة من التكنولوجيا الحديثة في

تطوير التعليم وتصميم البرمجيات اللغوية
خاتمة

سلطت الدراسة الضوء على عدد من النقاط حول محور لغوي بات النظر في إعادة هيكلته من عنداء الأمور الملحة التي تتطلبها منهجيات التدريس الحديثة لاسيما في الحقل اللغوي في عصر يعصف الألف

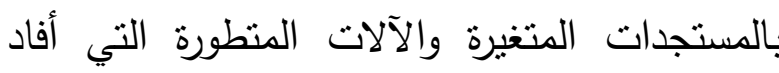
منها العالم والمتعلم على حد سواء في كافة مجالات العلوم الإنسانية، ولغتتا العربية بحاجة إلى العناية

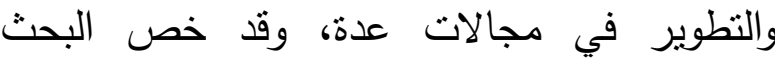

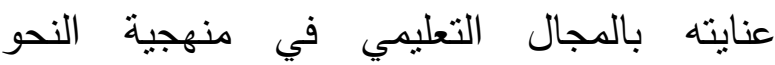
المدرسي، ومدى الإفادة من قسم من المعطيات فئهات فئهي

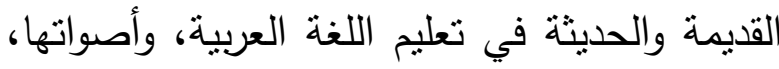
وصرفها، ونحوها، واملائها، وما لها من أثر في تخطي هاجس الخوف من دراسة اللغة العربية، والنفور من الانخراط في دراسة قواعد لغتها ونحوها. وقد قامت الدراسة على عدد من المحاور، وأسفرت نتائجها عن أن المناهج التعليمية، وفقاً

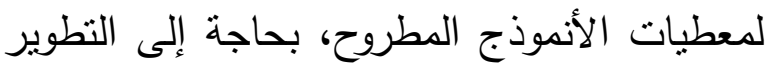

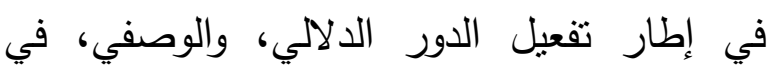
منهجية دراسة النحو العربي، مع ضرورة تفعيل فهر اللغة العربية في سياق نصوصها الحية، ويمكن أن نجمل هنا مجموعة من النتائج والتوصيات، وهي كالآتي: - ن

1. إن تقعيد العربية يجب أن ينطلق

من حقيقة كون اللغة ذات قيمة وظيفية، وأنها وسيلة الكلام والإبناغ. 


$$
\begin{aligned}
& \text { الأزهري، خالد، شرح التصريح على التى الكياء } \\
& \text { التوضيح، دار إحياء الكتب العربية: القاهرة. }
\end{aligned}
$$

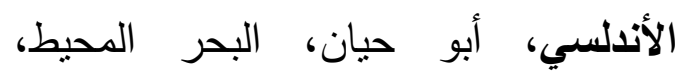

$$
\begin{aligned}
& \text { تحقيق: عادل عبد الموجود، علي معوض، داري، البرار }
\end{aligned}
$$

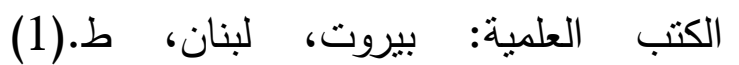

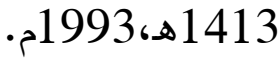

$$
\begin{aligned}
& \text { التوحيدي، أبو حيان، الإمتاع والمؤانسة، } \\
& \text { تصحيح وضبط: أحمد أمين وأحمد الزين، الآنا } \\
& \text { منشورات دار مكتبة الحياة: بيروت، لبنان. }
\end{aligned}
$$

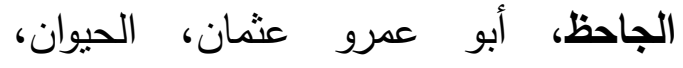

$$
\begin{aligned}
& \text { تحقيق: عبدالسلام هارون، القاهرة 1356هـ أبـان، } \\
& \text { الجرجاني، عبدالقاهر، دلائل الإعجاز ، دار }
\end{aligned}
$$

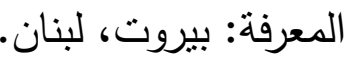

$$
\begin{aligned}
& \text { حسان، تمام، اللغة العربية معناها ومبناها، }
\end{aligned}
$$

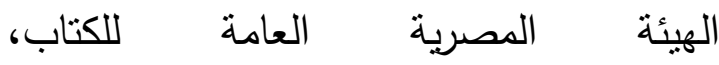

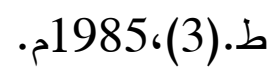

$$
\begin{aligned}
& \text { حسان، تمام، مناهج البحث في اللغة، دار } \\
& \text { الثقافة: الدار البيضاء، 1986م. } \\
& \text { حسين، عبد القادر، أثز النحاة في الدرس الناء } \\
& \text { البلاغي، دار غريب: القاهرة. } \\
& \text { الالابيح، محمد فضل تلجي، دليل القاعدة } \\
& \text { النحوية عند سيبويه، دار الكتاب الثقافي: إربد، التاعل }
\end{aligned}
$$

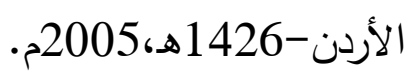

$$
\begin{aligned}
& \text { الزجاجي، أبو القاسم، الإيضاح في علل }
\end{aligned}
$$

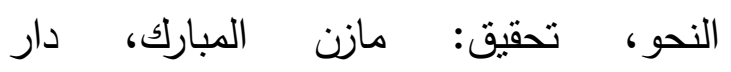

$$
\begin{aligned}
& \text { النفائس:بيروت، ط.(1)1394هـ1974م. }
\end{aligned}
$$

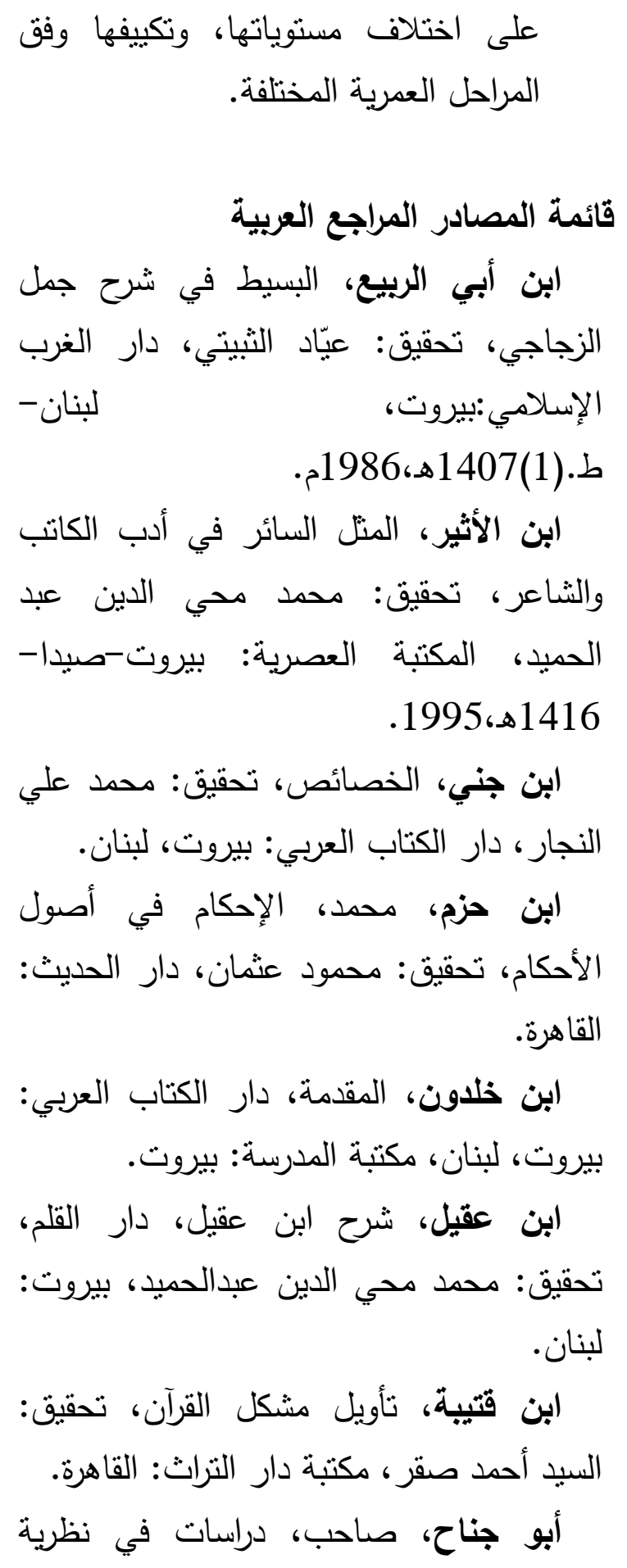




$$
\begin{aligned}
& \text { الشنتمري، الأعلم، تحصيل عين الذهب من } \\
& \text { الزجاجي، أبو القاسم، الجمل في النحو، } \\
& \text { معدن جوهر الأدب في علم مجازات العرب، } \\
& \text { تحقيق: علي الحمد، مؤسسة الرسالة: } \\
& \text { بيروت،لبنان، ط.(5) 1417هـ، 1996م. } \\
& \text { ط.(3) 1415هـ، 1994م. } \\
& \text { الزجاجي، مجالس العلماء، تحقيق: عبد } \\
& \text { السلام هارون، الكويت، 1962م. مالتهين }
\end{aligned}
$$

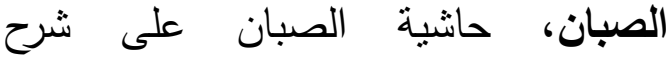

$$
\begin{aligned}
& \text { الأشموني على ألفية ابن ماللك، دار إحياء } \\
& \text { الكتب العربية: القاهرة، فيصل عيسى البابي الائي مائ داءي } \\
& \text { الحلبي. } \\
& \text { عبد المتعال الصعيدي، النحو الجديد، دار }
\end{aligned}
$$

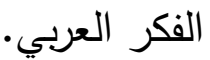

$$
\begin{aligned}
& \text { عبداللطيف، محمد حماسة، النحو والدلالة، } \\
& \text { مطبعة المدينة:القاهرة، ط.(1)1983م. }
\end{aligned}
$$

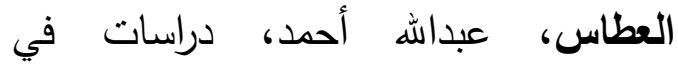

$$
\begin{aligned}
& \text { التوظيف المسرحي، مطبوعات نادي مكة لهئ }
\end{aligned}
$$

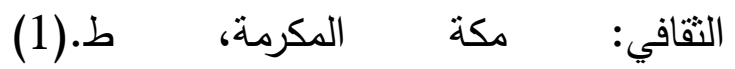

$$
\begin{aligned}
& \text { 1430هـ، 2009م. } \\
& \text { الغزالي، أبو حامد، المستصفى في علم }
\end{aligned}
$$

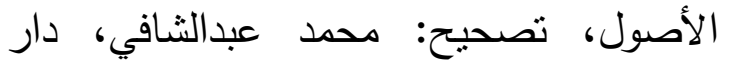

$$
\begin{aligned}
& \text { الكتب العلمية: بيروت، لبنان، 1420هـ، 2000م. } \\
& \text { ياقوت، أحمد سليمان، أبحاث في اللغة، دار لينان }
\end{aligned}
$$

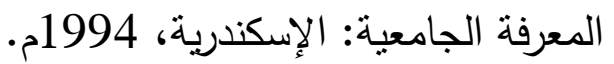

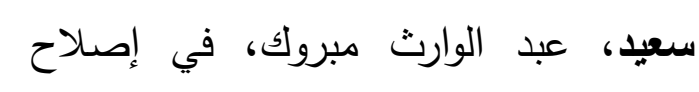

$$
\begin{aligned}
& \text { النحو العربي دراسة نقدية، دار القلم: الكويت. }
\end{aligned}
$$

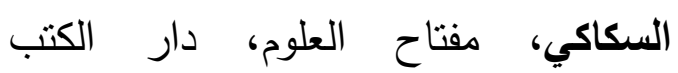

$$
\begin{aligned}
& \text { العلمية:بيروت، لبنان. } \\
& \text { سييويه، الكتاب، تحقيق:عبد السلام هارون، } \\
& \text { الخانجي:القاهرة، } \\
& \text { مكتبة } \\
& \text { ط.(3)، 1408هـ، 1988، 1988م. } \\
& \text { السيرافي، أبو سعيد، أخبار النحويين }
\end{aligned}
$$

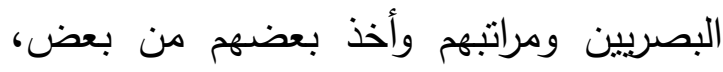

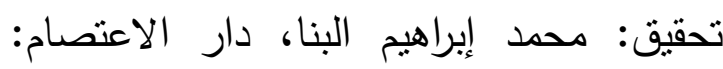

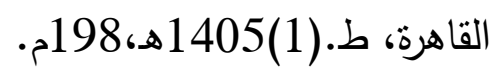




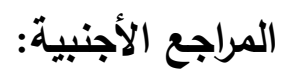

Benz, Anton, Jäger Gerhard, Rooij, Van, Robert (edited), Game theory and pragmatics, Palgrave Macmillan, 2006.

Blutner, Rienard, Berlin, Lexical Semantics and Pragmatics, Intercultural Pragmatics, Linguistics-communication Journal, volume 3-nomber1, 2006.
Firth, J.R. (1957) Papers in Linguistics, Oxford University Press.

Trask, R.L. Key concept in language and linguistics, Routledge:London, 1999. 


\title{
Vision in Functional Semantics: Toward the Establishment of Modern Methods in Syntax Teaching
}

\author{
Khulud al-salih
}

King Abdulaziz University

\begin{abstract}
The aim of this study is to direct attention to the importance of the semantic aspects as an integral component when we come to teaching Modern Arabic. This study advises Arabic teachers to forsake the prescriptive methods that neglect these semantic aspects. Our aim here is to stress the need to review our present language teaching methods and call in this endeavor for reconsidering the early Arabic traditional linguistic thought that gave considerable attention to the semantic part of the language teaching.

This study applies descriptive and functional methods based on surveying and analyzing language curriculum sources applied in girls' high schools in Saudi Arabia

The study is divided into four sections. The first, introduces the problem and points out the importance of this study. It also reviews the various views maintained by contemporary or old Arabic scholars as they dealt with the issues of the teaching methods.

The second section discusses the semantic position in the classical linguistic Arabic thought. It shows that the study of syntax was an integrated process that linked semantic and structural elements together in the case of expressing or finding meaning.

The third section investigates the teaching methods employed in High school curriculums. The attempt is made to point out the side effects of these methods and to emphasizes the need to improve them by taking into consideration the semantic sides of the process.

The fourth section attempts to offer a new teaching method based on functional processes related to teaching language through contexts, stories, and dialogue. Finally, the study concludes with submitting its findings and suggesting some recommendations

Keywcrda: Arabic Grawwer- Semantics- Syntax Teaching
\end{abstract}

